\title{
Multiple Hazards and Governance Model in the Barranquilla Metropolitan Area, Colombia
}

\author{
Celene B. Milanes ${ }^{1}{ }^{(}$, Marina B. Martínez-González ${ }^{2}{ }^{\circledR}$, Jorge Moreno-Gómez ${ }^{3}{ }^{\circledR}$, Ana Saltarín J. ${ }^{4,5}$, \\ Andres Suarez ${ }^{1}{ }^{\mathbb{D}}$, Samuel E. Padilla-Llano ${ }^{6}{ }^{(}$, Alex Vasquez $^{2}$, Seweryn Zielinski ${ }^{7, * \mathbb{D}}$ and Allan Lavell ${ }^{8}$ \\ 1 GeMarc and GESSA Research Groups, Department of Civil and Environmental Engineering, Universidad de \\ la Costa, Barranquilla 080001, Colombia; cmilanes1@cuc.edu.co (C.B.M.); asuarez24@cuc.edu.co (A.S.) \\ 2 Department of Social Science, Universidad de la Costa, Barranquilla 080001, Colombia; \\ mmar-tine21@cuc.edu.co (M.B.M.G.); avasquez2@cuc.edu.co (A.V.) \\ 3 Department of Business Studies, Universidad de la Costa, Barranquilla 080001, Colombia; \\ jmo-reno@cuc.edu.co \\ 4 Risk Management Office, Barranquilla City Hall, Barranquilla 080001, Colombia \\ 5 GeMarc Research Group, Universidad de la Costa, Barranquilla 080001, Colombia; asaltari1@cuc.edu.co \\ 6 ARUCO Research Group, Tii Research Grou, Department of Architecture and Design, Universidad de la \\ Costa, Barranquilla 080001, Colombia; spadilla13@cuc.edu.co \\ 7 Department of Hospitality and Tourism Management, Sejong University, Seoul 05006, Korea \\ 8 FLACSO, Curridabat 11801, San Jose Province, Costa Rica; allanmlavell@gmail.com \\ * Correspondence: sew.zielinski@gmail.com
}

\section{check for} updates

Citation: Milanes, C.B.; Martínez-González, M.B.; Moreno-Gómez, J.; Saltarín J., A.; Suarez, A.; Padilla-Llano, S.E.; Vasquez, A.; Zielinski, S.; Lavell, A. Multiple Hazards and Governance Model in the Barranquilla Metropolitan Area, Colombia. Sustainability 2021, 13, 2669. https://doi.org/10.3390/su13052669

Academic Editor: Wei-Ta Fang

Received: 24 January 2021

Accepted: 23 February 2021

Published: 2 March 2021

Publisher's Note: MDPI stays neutral with regard to jurisdictional claims in published maps and institutional affiliations.

Copyright: (C) 2021 by the authors. Licensee MDPI, Basel, Switzerland. This article is an open access article distributed under the terms and conditions of the Creative Commons Attribution (CC BY) license (https:// creativecommons.org/licenses/by/ $4.0 /)$.

\begin{abstract}
The Barranquilla Metropolitan Area is exposed and often vulnerable to various natural and anthropogenic hazards. The paper's main objective is to identify the level of understanding that local and regional institutions have of such a multi-hazard scenario, as well as the effectiveness of governance arrangements in minimizing impacts. Research employed a questionnaire applied to 115 stakeholders from government and a survey of 391 households from four communities in the study area. Four focus groups were held during the update of the Barranquilla Development Plan 2020-2023. The results allowed the identification of an updated set of hazards and the levels of government response capacity. The overall level of capacity and effectiveness of local government to respond to hazards was classified as regular. Seventy-seven percent of epistemic 'experts considered that the institutions responsible for risk management did not undertake sufficient analysis for identifying and managing multiple hazards. Finally, the research team developed a new model of risk management.
\end{abstract}

Keywords: urban flooding; risk and disasters; vulnerabilities; governance; decision making; exposure; probability; hazard; sustainable cities

\section{Introduction}

Metropolitan cities are increasingly vulnerable to natural and anthropogenic hazards [1-4]. In many of these cities, large river floods have become a major source of risk $[5,6]$. Vulnerabilities intensify due to population growth and poor urban development in highly exposed areas [7,8]. At the same time, factors such as the deficient or null provision of relevant urban services by government prior to and after an event further increases the overall quotidian and disaster risks. All the above-mentioned factors affect the efficiency and relevance of risk management [9].

Different types of floods are identified in the literature on the topic. These include coastal floods due to storms, sea-level rise associated with climate change, wave action, and inland storm surge $[10,11]$. River floods may occur due to heavy rainfall and river overflow in the section of the floodplain closest to the sea, among other causes [12,13]. Two different mechanisms can generate urban flooding: (a) a town or city that occupies a part 
of the floodplain is flooded by events of external origin, (b) floods generated by internal urban fluvial and wastewater runoff [14].

In the Barranquilla Metropolitan Area (BMA), the potential flooding associated with the patterns of territorial expansion and rapid urban growth was never considered by planning authorities. Floods occur in Barranquilla due to (a) the intensity and duration of tropical rainfall events and high pluvial flow rates [15]; (b) the magnitude of the hazard, urban occupation of stormwater runoff channels and beaches, as well as the waterproofing of absorbent surfaces in the river basins.

The lack of drainage systems in most areas of the city, as well as the occurrence of highly hazardous flash floods, constitute a challenge for urban risk management [16,17]. The Barranquilla District Government has invested heavily in the construction of a robust stormwater runoff channel system. However, scant investment in raising the levels of civic culture and in stimulating the appropriation and empowerment of citizens with reference to the works carried out has impeded the participation of the local population in the protection and conservation of these works. Continuous dumping of solid waste has been observed in channeled and non-channeled streams. Regular flooding has caused accidents, loss of cars, damage to infrastructure, and on average, around two human deaths a year $[18,19]$. Indirect effects on livelihoods, income, employment, amongst other factors, constitute the systemic risk impacts of primary events. Floods mainly occur in central areas of Barranquilla city and areas bordering the Magdalena River [20].

Although urban flooding is an important hazard in the BMA, it is not the only hazard present. However, low risk perception by impacted communities impedes sufficient consideration and analysis of these.

In this article, risk perception is defined in terms of the level of awareness of local government, community, public and private enterprise organizations, and institutions when faced with multiple hazards and which affects the taking of risk reduction decisions. This is conditioned by the understanding of the existing levels of vulnerability, probability of damage and possible losses.

In Barranquilla, the capital city of the BMA, streams run from and over the city's western slopes. These slopes are occupied principally by low-income families and communities with high levels of socioeconomic vulnerability. The demographic pressure on these territories has increased due to the migration of people displaced by different forms of internal conflict in Colombia and of Venezuelans due to the country's economic and political situation [21].

The first flooding incident occurring in Barranquilla was registered in 1916 [22]. However, it is in the period 2010-2011 that the area was impacted by the historically most severe natural event ever suffered ("La Niña") [23]. This Niña event led to the entire city, particularly neighborhoods on the western slopes, suffering severely from landslides and stream flooding $[10,24]$. As of that date, a serious search to identify and understand the causes and effects that these hazards represent for the district began, and a firm intention has been expressed to develop actions that increase urban resilience.

Beyond flood impacts, the BMA faces other challenges that limit its sustainable development. Hurricanes in the Caribbean basin and tornadoes' affect the region periodically [25]. Additionally, medium term projections suggest that the BMA will be severely affected by climate change with consequences in terms of coastal erosion, increase in the intensity and frequency of winds and flooding, among others [13]. The lack of prioritization of these hazards in local risk management policies contributes to the existing low level of urban resilience. In principle, this is due to the insufficient appropriation of risk knowledge, a lack of cross-sectoral coordination, different levels of risk tolerance, and the lack of implementation of measures to mitigate the event's consequences.

Resilience is a broad concept and can be defined in different ways depending on how and in what scientific area the term is applied [26]. These include ecological [27], engineering [28], psychological [29,30], community [31], and urban resilience [32,33]. This latter concept is increasingly employed in the international scientific literature and, as risks 
to the urban population increase, urban resilience gains relevance in the major international development agendas.

Urban resilience refers to the capacity for overcoming the impact of natural and anthropogenic hazards and the associated vulnerabilities of affected populations [23]. Facing risks through an effective institutional and governmental response, with adequate citizen participation can significantly help recover adequate levels of social security, employment, income, and quality of life for citizens, after they have experienced the negative impact of one or more hazards [34,35].

Although the local government of Barranquilla implements actions and attempts to promote a resilient urban model, the BMA is still not part of the City Resilience Profiling Program (CRPP) promoted by UN-Habitat [36]. In fact, no city in Colombia is part of this program. The local government of Barranquilla attempts to respond to the different hazards by promoting governance processes that increase the presence of urban risk management principles and practice. However, they have not yet managed to respond to the social demands and prospective management needs of the BMA [16].

This paper proposes a model for improving public policies based on governance for the integral management of disaster risk. This model must include increases in the levels of institutional knowledge and understanding of urban hazards, the participation of citizens or civil society in evaluating risks, the design, development, and operation of risk reduction and disaster response measures, and in the government's effectiveness to respond to the impacts of hazards and institute risk reducing recovery processes.

The article comprises four sections. The first addresses the updated set of hazards identified by government institutions, as well as the government's capacity to respond to emergencies. The second section evaluates the perception of hazards and risks. This process aims to comprehensively understand how different stakeholders at different levels perceive risk in the BMA. The level of effectiveness of government entities in managing the multiple hazard scenarios is evaluated in the third section. At the same time, the weaknesses and strengths detected in public policy aimed at the governance of the identified hazards, with special attention to urban floods, are synthesized. The fourth and last section presents a novel model for integrated risk management and for increasing the urban resilience of the BMA.

\section{Materials and Methods}

To gain greater clarity as to management and action when faced with flooding, it is essential to measure the differential perceptions of stakeholders [37] in relation to risk management. This includes stakeholders from community, government, civil society, and scientific institutions. For the present research endeavor, we identified stakeholder experts considering their epistemic and on the job expertise [38]. Epistemic experts were able to provide justifications for a range of propositions according to their expert domain (professionals in risk management). While on the job, experts were selected considering their empirical practice and skill with issues of hazards and risks.

Figure 1 shows the steps followed for the analysis, collection, and processing of information. In the following section, details of each stage are provided.

\section{The Methodological Framework Followed in the Research}

First stage: we undertook an in-depth documentary review, consulting and analyzing different bibliographic sources that report on river flooding in the BMA, with a record between 2010 and 2020 [39-41]. At the same time, we analyzed and synthesized the presence of social, epidemiological, natural, and anthropogenic hazards using the following documentary sources: Land Use and Management Plans (POMCAS) for River Basins in the department of Atlántico (Magdalena, Mallorquin, and Canal de Dique) [42-44], Comprehensive Management Plan for the western slopes of Barranquilla [45], Development Plan 2016-2019 for the Atlantic Department [46], reports related to the Streams Master Plan for the District of Barranquilla [47], Land Use Plan for Barranquilla [24], the Atlantic Vision 
2020 Agenda [48], Decree No. 0212 of 2014 [49], a GIZ sponsored report on Socio-spatial Segregation, Disaster Risk, and it's Management [50] as well as graduate theses [51].

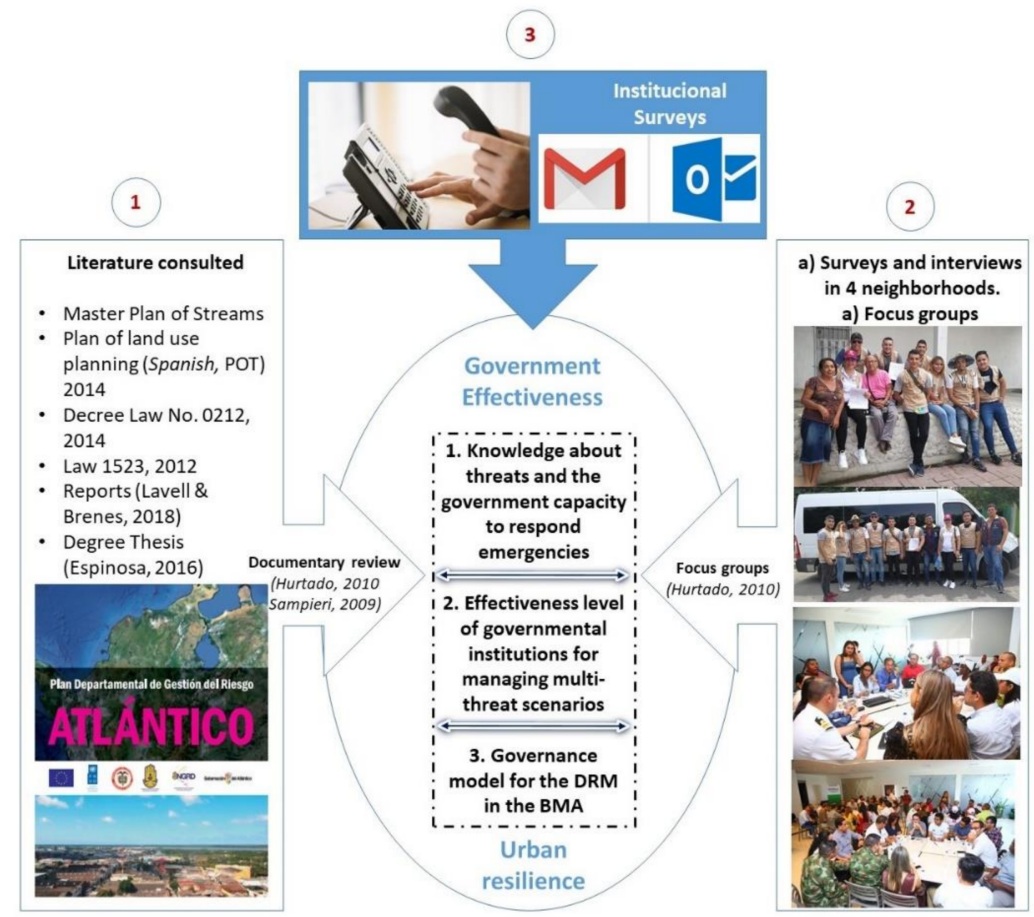

Figure 1. Research framework. (Source: the authors).

Second stage: this was developed in two phases. The first evaluates the perception of risk in four communities. A questionnaire was conducted with 391 households in four neighborhoods of the BMA (La Cangrejera, Adelita de Char, Nueva Colombia, and La Esmeralda). We considered older neighborhoods with dense populations located in high-risk areas and with a sense of belonging among the communities. These places are characterized by a marked inequality (the most evident social problem in the city), low urban service endowment, poor socioeconomic conditions, and high exposure to hazard. Furthermore, a significant proportion of the population lives on slopes and is affected by landslides, floods, and fluvial runoff. The questionnaire sought to understand the level of knowledge existing as to what to do when facing hazardous events in the neighborhoods; and also, respondents' levels of exposure to hazards and their perception of these.

In the second phase of stage 2, four focus groups or participatory roundtables were held with experts on 5 March 2020 [52,53]. The objective was to measure the perception of stakeholders (on the job, performance experts) as to the effectiveness of the government management of urban risk when faced with the different hazards present in the BMA. To this end, a weakness-strengths matrix was applied. We also collected information regarding actions and recommendations on risk management that experts considered should be included in the Barranquilla Development Plan in the period 2020-2023 [54].

The focus groups included 75 performance experts. These persons were employees, and executives working in disaster risk management (DRM), (see Appendix A). Those included the business and industrial sectors, military and government, relief agencies, carnival operators, the academic community (the heads of Higher Education Institutions such as Universidad de la Costa, Universidad del Norte, and the Simon Bolivar University). Furthermore, officials from the Fluvial Maritime Committee, several companies that supply inputs for risk management, and specialized consultants also participated.

At this stage, the research work was enriched with contributions from the Office of the Mayor of Barranquilla (www.barranquilla.gov.co), specifically from the Office of Risk Management (www.barranquilla.gov.co/gestion-del-riesgo). This is the institution in 
charge of identifying hazards, vulnerabilities, and managing risk in the BMA. We also consulted employees of leading institutions, such as the Public Environmental Establishment "Barranquilla Verde" (www.barranquillaverde.gov.co) and the "Autonomous Regional Corporation of Atlántico" (www.crautonoma.gov.co).

Third stage: we undertook surveys using a structured questionnaire applied to forty epistemic experts from regional and local government institutions working on risk management in the BMA (see Appendix A). The questionnaire was designed following the methodology developed by Hurtado in 2010 [55]. The questionnaire had five parameters or points of reference: (1) hazards of natural origin, which were sub-classified into geological and hydrological hazards, (2) hazards of technological origin, (3) hazards of anthropogenic origin, (4) hazards of social origin, and (5) hazards of epidemiological and health origin. The questionnaire was answered directly by the stakeholder without the intervention of a third party. The surveys were distributed by email. Participants were also informed of this survey through phone calls. The questionnaire allowed them to freely identify hazards in the BMA, following the Departmental Risk Management Plan for the Atlántico Department [39].

Concerning multi hazard contexts, the epistemic experts were asked to specify the degree of severity of each hazard, considering five variables, namely:

(1) Probability: the possibility that the hazard may occur at a certain time and place. This is measured using the following evaluation scale: 5 (totally probable), 4 (moderately probable), 3 (occasionally probable), 2 (rarely probable), 1 (null or improbable).

(2) Frequency: temporal recurrence of the hazard in the BMA. This variable was measured according to the following scale: 1 (never), 2 (sporadically), 3 (moderately), 4 (almost always), and 5 (always).

(3) Exposure: the exposure level of the BMA to each hazard. The evaluation scale is as follows: 1 (null), 2 (very light), 3 (medium), 4 (severe), and 5 (very severe).

(4) Area affected: territorial space of the BMA that is affected by the hazard: The evaluation scale is: 1 (house), 2 (neighborhood), 3 (commune), 4 (Barranquilla district), 5 (all the BMA).

(5) Ability of the local government to measure the level of capacity of the local government to respond to each hazard in the BMA. The evaluation scale is: 1 (no capacity), 2 (light capacity), 3 (medium capacity), 4 (high capacity), and 5 (very high capacity).

At this stage also, the epistemic experts were asked to freely list the governments' weaknesses and strengths in searching to solve the problem of hazards.

All the questionnaires were processed on 3 July 2020, with a response rate of $95 \%$.

\section{Case Study of Barranquilla Metropolitan Area (BMA)}

Barranquilla is the fourth largest metropolitan area in Colombia, with 2.7 million inhabitants [54]. The BMA is located in the northern coastal area, with free access to the Atlantic Ocean and the Caribbean Sea, on the banks of the great Magdalena River. The other municipalities that make up the BMA are situated in the intermediate rural periphery between river and sea (See Figure 2). 


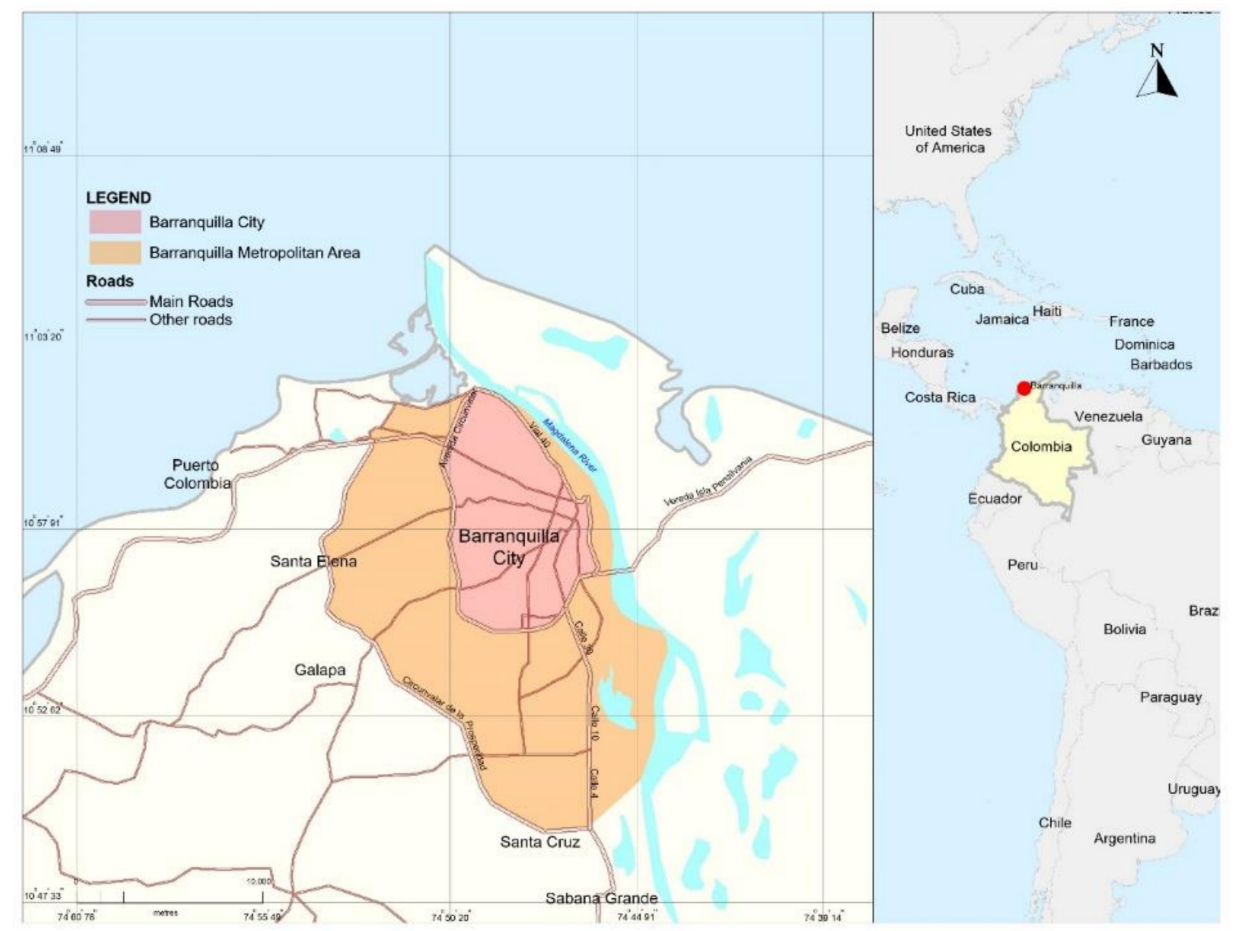

Figure 2. Geographical location of Barranquilla Metropolitan Area (BMA) (Source: Prepared by the authors).

Urban segregation and inequality are prevalent in the BMA. For several years, the study area has been subjected to a development model that facilitated the emergence of significant inequity and environmental problems, putting the most impoverished communities at high levels of latent risk.

During the first decades of the 20th century, the economic dynamic of the city led to accelerated demographic growth, associated with the migratory process from the countryside to the city. The city's expansion to the northwest and south generated two different socioeconomic patterns associated with the business elite and the working population. The northwest expansion occurred with housing and service provision for a population with greater economic resources and to the south with working class housing due to lower incomes [56]. Parallel to these planned developments, land invasions have occurred, especially in the southwest. These are what are termed "sub-normal" neighborhoods lacking many essential public services. As the city grew, issues such as informality, the government's inability to generate development policies for the entire population and corruption led to the lack of opportunities and means for achieving socially more just and equitable investment [56].

Currently, the city faces severe spatial problems related to the lack of planning and the tendency to privilege dominant economic groups. Regional economic elites have played a decisive role in the adaptation of the territory to their needs using the control of state powers, territorial planning, infrastructure construction, among other processes, to achieve this [57]. As a result, an important part of the city's inhabitants occupy territories unsuitable for urban habitation, in many cases, perpetuating conditions of poverty and vulnerability in social, economic, and environmental terms [58]. The area of study has significant relevance for analyzing multi-hazard, governance, and risk management scenarios.

\subsection{Results}

3.1.1. Identification of Hazards, Government Capacity to Respond to Emergencies, and the Perception of Hazards and Risks by Communities in the BMA.

Identification of the multi-hazard scenario in the BMA was achieved through a literature review and surveys and revealed 36 different hazards (See Tables 1 and 2). 
Table 1. Identification of hazards in the BMA according to literature consulted (Source: Elaborated by the authors).

\begin{tabular}{|c|c|c|c|c|c|c|c|c|c|c|c|c|c|c|c|}
\hline \multirow[b]{2}{*}{ No } & & \multirow[b]{2}{*}{ Type } & \multirow[b]{2}{*}{ Hazard } & \multirow[b]{2}{*}{ 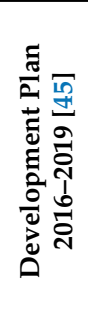 } & \multirow[b]{2}{*}{ 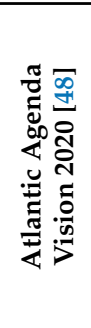 } & \multicolumn{3}{|c|}{ POMCAS [42-44] } & \multirow[b]{2}{*}{ 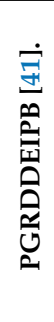 } & \multirow[b]{2}{*}{ 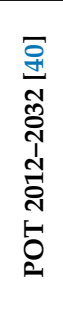 } & \multirow[b]{2}{*}{ 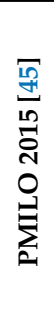 } & \multirow[b]{2}{*}{ 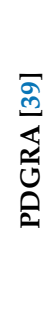 } & \multirow[b]{2}{*}{ 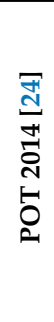 } & \multirow[b]{2}{*}{ 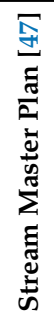 } & \multirow[b]{2}{*}{ 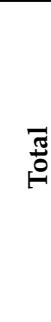 } \\
\hline & & & & & & 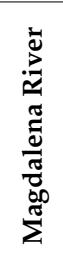 & 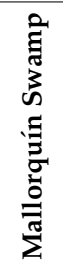 & 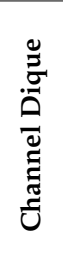 & & & & & & & \\
\hline 1 & \multirow{14}{*}{$\begin{array}{l}\overrightarrow{\widetilde{J}} \\
\stackrel{\Xi}{\Xi} \\
Z\end{array}$} & & Landslides & $\mathrm{x}$ & $\mathrm{x}$ & $\mathrm{x}$ & $\mathrm{x}$ & $\mathrm{x}$ & & $\mathrm{x}$ & $\mathrm{x}$ & $\mathrm{x}$ & $\mathrm{x}$ & $\mathrm{x}$ & 10 \\
\hline 2 & & & Granular flows & $\mathrm{x}$ & $\mathrm{x}$ & $\mathrm{x}$ & & $\mathrm{x}$ & & & $\mathrm{x}$ & $\mathrm{x}$ & $x$ & $\mathrm{x}$ & 8 \\
\hline 3 & & త్ర & Liquefaction & & & & $\mathrm{x}$ & & & $\mathrm{x}$ & $\mathrm{x}$ & $\mathrm{x}$ & $\mathrm{x}$ & $\mathrm{x}$ & 6 \\
\hline 4 & & $\frac{60}{0}$ & Tsunami/tidal wave & $\mathrm{x}$ & & & & & $\mathrm{x}$ & $\mathrm{x}$ & & $\mathrm{x}$ & $\mathrm{x}$ & & 5 \\
\hline 5 & & & Earthquake & $\mathrm{x}$ & & & $\mathrm{x}$ & $\mathrm{x}$ & $\mathrm{x}$ & $\mathrm{x}$ & & $\mathrm{x}$ & $\mathrm{x}$ & $\mathrm{x}$ & 8 \\
\hline 6 & & & Volcanic mud and gas flows & $\mathrm{x}$ & & & $\mathrm{x}$ & $\mathrm{x}$ & $\mathrm{x}$ & $\mathrm{x}$ & & & & $\mathrm{x}$ & 6 \\
\hline 7 & & & Coastal erosion & $x$ & $\mathrm{x}$ & $\mathrm{x}$ & $\mathrm{x}$ & $\mathrm{x}$ & $\mathrm{x}$ & $\mathrm{x}$ & $\mathrm{x}$ & $\mathrm{x}$ & $x$ & & 10 \\
\hline 8 & & & Hurricanes & $\mathrm{x}$ & & & & $\mathrm{x}$ & & & $\mathrm{x}$ & $\mathrm{x}$ & $\mathrm{x}$ & & 5 \\
\hline 10 & & 80 & Electrical storms & & & & & $\mathrm{x}$ & & & & $\mathrm{x}$ & & & 2 \\
\hline 11 & & : & Droughts and desertification & & & $\mathrm{x}$ & & & & $\mathrm{x}$ & $\mathrm{x}$ & $\mathrm{x}$ & & & 4 \\
\hline 12 & & $\vec{\Xi}$ & Flood by upswelling & & & & & & & & & $\mathrm{x}$ & $\mathrm{x}$ & & 2 \\
\hline 13 & & $\frac{0}{0}$ & Flood by streams & $\mathrm{x}$ & $\mathrm{x}$ & $\mathrm{x}$ & & $\mathrm{x}$ & $\mathrm{x}$ & $\mathrm{x}$ & $\mathrm{x}$ & $\mathrm{x}$ & $\mathrm{x}$ & $\mathrm{x}$ & 10 \\
\hline 14 & & & Flood due to heavy rains & & & & & & & & & $\mathrm{x}$ & & $\mathrm{x}$ & 2 \\
\hline 15 & & & Sea level rise & & & & $\mathrm{x}$ & & $\mathrm{x}$ & $\mathrm{x}$ & & $\mathrm{x}$ & & & 4 \\
\hline 16 & \multirow{4}{*}{\multicolumn{2}{|c|}{ 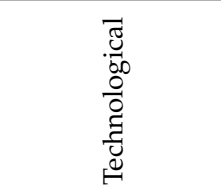 }} & Toxic gas leaks & & & & & & & & & $\mathrm{x}$ & & & 1 \\
\hline 17 & & & Explosions & $\mathrm{x}$ & & $\mathrm{x}$ & & $\mathrm{x}$ & & & & & & & 3 \\
\hline 18 & & & Oil spills & $\mathrm{x}$ & & $\mathrm{x}$ & & & & $\mathrm{x}$ & & $\mathrm{x}$ & & & 4 \\
\hline 19 & & & Structural fire & $\mathrm{x}$ & & & & & $\mathrm{x}$ & $\mathrm{x}$ & $\mathrm{x}$ & $\mathrm{x}$ & $\mathrm{x}$ & & 6 \\
\hline
\end{tabular}


Table 1. Cont.

\begin{tabular}{|c|c|c|c|c|c|c|c|c|c|c|c|c|c|c|}
\hline \multirow[b]{2}{*}{ No } & \multirow[b]{2}{*}{ Type } & \multirow[b]{2}{*}{ Hazard } & \multirow[b]{2}{*}{ 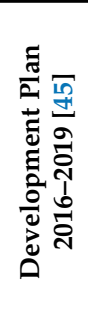 } & \multirow[b]{2}{*}{ 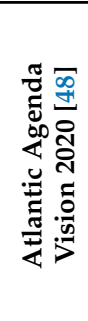 } & \multicolumn{3}{|c|}{ POMCAS [42-44] } & \multirow[b]{2}{*}{ 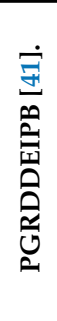 } & \multirow[b]{2}{*}{ 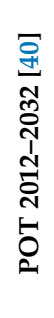 } & \multirow[b]{2}{*}{ 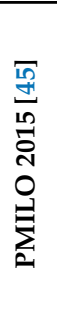 } & \multirow[b]{2}{*}{ 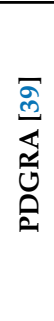 } & \multirow[b]{2}{*}{ 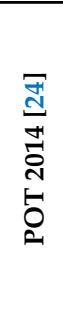 } & \multirow[b]{2}{*}{ 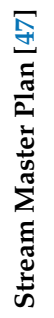 } & \multirow[b]{2}{*}{ 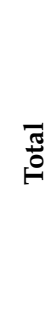 } \\
\hline & & & & & 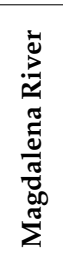 & 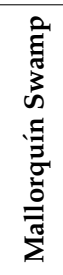 & 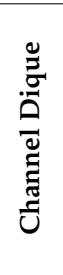 & & & & & & & \\
\hline 20 & \multirow{5}{*}{ 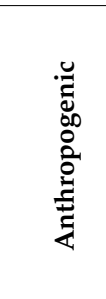 } & Environmental degradation & $\mathrm{x}$ & $\mathrm{x}$ & & $\mathrm{x}$ & & $\mathrm{x}$ & $\mathrm{x}$ & & $\mathrm{x}$ & $x$ & & 7 \\
\hline 22 & & Contamination by solid waste & & & $\mathrm{x}$ & & $\mathrm{x}$ & $\mathrm{x}$ & & & $\mathrm{x}$ & $\mathrm{x}$ & & 5 \\
\hline 23 & & Air pollution & & $\mathrm{x}$ & $\mathrm{x}$ & & $\mathrm{x}$ & $\mathrm{x}$ & $\mathrm{x}$ & $\mathrm{x}$ & $\mathrm{x}$ & $\mathrm{x}$ & & 8 \\
\hline 24 & & Forest fires & & & & & & $\mathrm{x}$ & & & $\mathrm{x}$ & $\mathrm{x}$ & & 3 \\
\hline 25 & & Colmatation $^{1}$ & & & & & & $\mathrm{x}$ & & & $\mathrm{x}$ & & & 2 \\
\hline 26 & \multirow{3}{*}{ 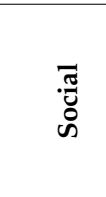 } & Extortion & & & & & & & & & & & & 0 \\
\hline 27 & & Poverty & & & & & & & & & & & & 0 \\
\hline 28 & & Sexual abuse & & & & & & & & & & & & 0 \\
\hline 30 & \multirow{7}{*}{ 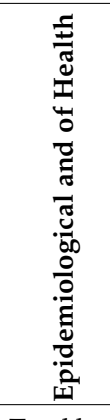 } & Malnutrition & & & & & & & & & & & & 0 \\
\hline 31 & & Infant mortality & & & & & & & & & & & & 0 \\
\hline 32 & & Sexually transmitted diseases & & & & & & & & & & & & 0 \\
\hline 33 & & Dengue & & & & & & & & & & & & 0 \\
\hline 34 & & Chicunguña & & & & & & & & & & & & 0 \\
\hline 35 & & Zika & & & & & & & & & & & & 0 \\
\hline 36 & & Covid 19 & & & & & & & & & & & & 0 \\
\hline \multicolumn{3}{|c|}{ Total by the source of information } & 13 & 6 & 11 & 8 & 12 & 12 & 14 & 10 & 23 & 16 & 8 & \\
\hline
\end{tabular}

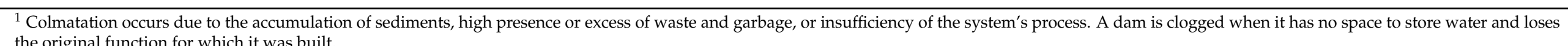
the original function for which it was built. 
Table 2. Survey of epistemic experts regarding the government's risk awarenesss and its response capacity.

\begin{tabular}{|c|c|c|c|c|c|c|c|c|c|c|c|c|c|c|c|c|c|c|c|c|c|c|c|c|}
\hline \multirow{2}{*}{$\mathbf{N}$} & \multirow{2}{*}{\multicolumn{2}{|c|}{ Type }} & \multirow{2}{*}{ Hazard } & \multirow{2}{*}{ Presence $(x)$} & \multicolumn{5}{|c|}{ Probability } & \multicolumn{5}{|c|}{ Frequency } & \multicolumn{5}{|c|}{ Exposition } & \multicolumn{5}{|c|}{ Affected Area } \\
\hline & & & & & 1 & 2 & 3 & 4 & 5 & 1 & 2 & 3 & 4 & 5 & 1 & 2 & 3 & 4 & 5 & 1 & 2 & 3 & 4 & 5 \\
\hline 1 & \multirow{13}{*}{$\begin{array}{l}\widetilde{\Xi} \\
\frac{\Xi}{\widetilde{Z}} \\
\end{array}$} & \multirow{6}{*}{$\begin{array}{l}\overline{\mathscr{S}} \\
60 \\
\overline{0} \\
\mathbb{0} \\
\mathbb{U}\end{array}$} & Landslides & 28 & & & 11 & 10 & 7 & & 15 & 6 & 1 & 6 & & 8 & 8 & 7 & 5 & 4 & 7 & 8 & 6 & 3 \\
\hline 2 & & & Granular flows & 33 & & 5 & 18 & 6 & 4 & & 11 & 15 & 3 & 4 & 2 & 8 & 5 & 14 & 4 & 4 & 4 & 9 & 10 & 6 \\
\hline 3 & & & Liquefaction & 34 & 1 & 16 & 11 & 6 & & 4 & 15 & 15 & & & 7 & 12 & 11 & 4 & & 2 & 5 & 16 & 5 & 6 \\
\hline 5 & & & Earthquake & 32 & 4 & 5 & 10 & 8 & 5 & 8 & 13 & 7 & & 4 & 6 & 8 & 7 & 5 & 6 & 6 & & 8 & 6 & 12 \\
\hline 6 & & & Volcanic mud and gas flows & 12 & 8 & 1 & 1 & 1 & 1 & 7 & 2 & 3 & & & 8 & 2 & 1 & 1 & & 5 & 4 & & 2 & 1 \\
\hline 7 & & & Coastal erosion & 15 & 3 & & & 7 & 5 & 2 & 1 & 4 & 3 & 5 & 1 & 2 & 5 & 4 & 3 & 2 & 1 & 2 & 5 & 5 \\
\hline 8 & & \multirow{7}{*}{$\begin{array}{l}\text { चే } \\
0 \\
0 \\
0 \\
0 \\
0 \\
0 \\
0 \\
0 \\
0 \\
0 \\
0 \\
0\end{array}$} & Hurricanes & 31 & 4 & & 8 & 10 & 9 & 7 & 5 & 13 & 6 & & & 3 & 9 & 12 & 7 & & 5 & 8 & 10 & 8 \\
\hline 9 & & & Gale Winds & 40 & & & 11 & 15 & 14 & & 7 & 13 & 12 & 8 & & 8 & 10 & 12 & 10 & 6 & 6 & 6 & 10 & 12 \\
\hline 11 & & & Droughts and desertification & 14 & & & 2 & 6 & 6 & 4 & I & 1 & 5 & 4 & & 1 & 5 & 4 & 4 & & 1 & 1 & 6 & 6 \\
\hline 12 & & & Flood by upwelling & 17 & & 2 & 8 & 2 & 5 & 1 & 2 & 10 & 3 & 1 & 2 & 2 & 5 & 6 & 2 & 1 & 1 & 6 & 4 & 5 \\
\hline 13 & & & Flood by streams & 40 & & 6 & 8 & 16 & 10 & & & 15 & 19 & 6 & & 7 & 7 & 18 & 8 & 5 & 7 & 6 & 11 & 11 \\
\hline 14 & & & Flood due to heavy rains & 35 & 6 & & 5 & 13 & 11 & & 6 & 11 & 8 & 10 & & 6 & 10 & 10 & 9 & 6 & 7 & & 12 & 10 \\
\hline 15 & & & Sea level rise & 12 & & 1 & 7 & 2 & 2 & 2 & 2 & 3 & 4 & 1 & 1 & 2 & 5 & 3 & 1 & 1 & 1 & 5 & 3 & 2 \\
\hline 16 & \multirow{4}{*}{\multicolumn{2}{|c|}{ 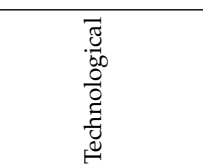 }} & Toxic gas leaks & 18 & 2 & 5 & 5 & 5 & 1 & 4 & 7 & 5 & 2 & & & 5 & 6 & 6 & 1 & & 5 & 6 & 4 & 3 \\
\hline 17 & & & Explosions & 17 & 3 & 2 & 6 & 5 & 1 & 2 & 9 & 4 & 2 & & & 4 & 6 & 5 & 2 & & 6 & 2 & 5 & 4 \\
\hline 18 & & & Spills & 18 & 2 & 2 & 7 & 5 & 2 & 5 & 7 & 5 & 1 & & & 5 & 6 & 6 & 1 & & 4 & 5 & 4 & 5 \\
\hline 19 & & & 1Structural fire & 16 & 3 & 1 & 4 & 6 & 2 & 2 & 2 & 4 & 7 & 1 & & 2 & 4 & 9 & 1 & 3 & 1 & 1 & 7 & 4 \\
\hline 20 & \multirow{4}{*}{\multicolumn{2}{|c|}{ 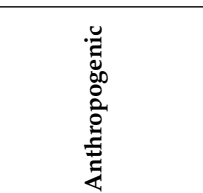 }} & Environmental degradation & 17 & 1 & 2 & 2 & 4 & 8 & 3 & 2 & 3 & 4 & 5 & 1 & & 8 & 5 & 3 & & 1 & 5 & 2 & 9 \\
\hline 23 & & & Air pollution & 20 & & 3 & 5 & 3 & 9 & 2 & & 5 & 6 & 7 & 4 & & 7 & 5 & 4 & & 1 & 5 & 5 & 9 \\
\hline 24 & & & Forest fires & 38 & 6 & 6 & 10 & 7 & 9 & 8 & 8 & 9 & 13 & & 7 & 7 & 15 & 9 & & & 8 & 6 & 13 & 11 \\
\hline 25 & & & Colmatation & 14 & & 1 & 2 & 7 & 4 & & 3 & 2 & 7 & 2 & & 2 & 2 & 8 & 2 & & & 2 & 8 & 4 \\
\hline 26 & \multirow{4}{*}{\multicolumn{2}{|c|}{$\begin{array}{l}\overline{.} \\
\text {. } \\
\text { के }\end{array}$}} & Extortion & 40 & & & 10 & 10 & 20 & & 8 & 8 & 10 & 14 & & 7 & 9 & 9 & 15 & & & & 14 & 26 \\
\hline 27 & & & Poverty & 38 & & & & 18 & 20 & & & 9 & 14 & 15 & & & 9 & 16 & 13 & & & 8 & 14 & 16 \\
\hline 28 & & & Sexual abuse & 21 & & 3 & 6 & 3 & 9 & & & 8 & 7 & 6 & & 2 & 9 & 4 & 6 & & 2 & 6 & 3 & 10 \\
\hline 29 & & & Drug addiction & 33 & 4 & 4 & 5 & 9 & 11 & & & 8 & 12 & 13 & & & 10 & 12 & 11 & & 6 & 7 & 7 & 13 \\
\hline 30 & \multirow{7}{*}{\multicolumn{2}{|c|}{ 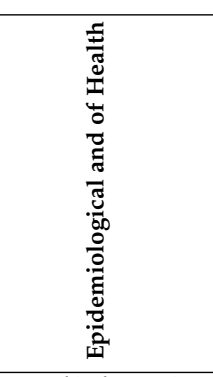 }} & Malnutrition & 38 & & 6 & 12 & 11 & 9 & & 6 & 14 & 9 & 9 & & 6 & 12 & 12 & 8 & & 7 & 10 & 9 & 12 \\
\hline 31 & & & Infant mortality & 16 & & 3 & 6 & 2 & 5 & & 3 & 9 & & 4 & & 2 & 10 & 1 & 3 & & 2 & 3 & 3 & 8 \\
\hline 32 & & & Sexually transmitted diseases & 16 & & & 5 & 5 & 6 & & 3 & 7 & & 6 & & & 8 & 2 & 6 & & 1 & 4 & 2 & 9 \\
\hline 33 & & & Dengue & 16 & & 1 & 3 & 5 & 7 & & 2 & 4 & 6 & 4 & & 1 & 4 & 8 & 3 & & 1 & 3 & 4 & 8 \\
\hline 34 & & & Chicunguña & 16 & 2 & 3 & 2 & 4 & 5 & & 4 & 4 & 5 & 3 & 1 & 3 & 3 & 7 & 2 & 2 & 3 & & 3 & 8 \\
\hline 35 & & & Zika & 16 & 1 & 4 & 2 & 6 & 3 & & 3 & 6 & 4 & 3 & 1 & 4 & 3 & 6 & 2 & 1 & 4 & & 4 & 7 \\
\hline 36 & & & Covid 19 & 40 & & 9 & 6 & 6 & 19 & & 9 & 9 & 10 & 12 & & 7 & 9 & 8 & 16 & & & & 16 & 24 \\
\hline otal by & & information & 37 & & & & & & & & & & & & & & & & & & & & & \\
\hline
\end{tabular}


Maximum values are represented by bolder colors.

Table 1 presents 25 hazards identified in the 11 risk management documents analyzed. With 23 hazards, the Atlantic Risk Management Departmental Plan [39] is the instrument that identifies and analyzes the largest number of events. The remaining plans and documents consulted $[24,40,47]$ only considered the presence of between 8 and 16 hazards in the study area. None of the documents analyzed identified hazards of a social, epidemiological, or health nature. This probably reflects the interpretation of hazard in disaster studies existing prior to SENDAI when a larger number of additional hazards, beyond the so-called natural and socio natural, were placed on the table, including health-related and epidemiological hazards. The most frequent hazards present in the documents are landslides, coastal erosion, and stream flooding. The three are hierarchically similar.

Table 2 registers the degree of probability, occurrence, frequency, and exposure to each of the 36 identified hazards assigned by epistemic experts. Contrary to the analysis developed in the documentary review, in this second stage, $100 \%$ of the experts consulted uniformly identified stream flooding and gale force winds as the natural hazards with the highest incidence in the BMA.

Only $37.5 \%$ of the experts recognized coastal erosion as a hazard with a high degree of probability, frequency, exposure, and coverage of affected territory. The other $62.5 \%$ did not consider that this hazard has a high level of incidence in the BMA.

COVID-19 stood out as the most important hazard for the BMA. Hazards of social origin, such as extortion, poverty, and drug addiction were also recognized by experts. These hazards endanger the lower social strata in particular. At the same time, electrical storms were identified by 18 surveyed experts. Landslides were not relevant for $55 \%$ of the experts consulted.

In addition to the set of hazards listed in Table 1,29 experts recommended that offshore hydrocarbon exploitation be considered a serious hazard.

According to the perceptions as to the efficiency of local government response, epistemic'experts identified stream flooding as the hazard where the government exercises greater response capacity. This is due to the high exposure to, and percentage of territory that historically has been affected by flooding (See Figure 3). The government and mayor's office have implemented different response mechanisms in order to face the emergencies caused by this hazard. Implementing hydraulic plans and the construction and cleaning of stream channels are part of the local government measures to minimize the risk (See Figures 4 and 5). 

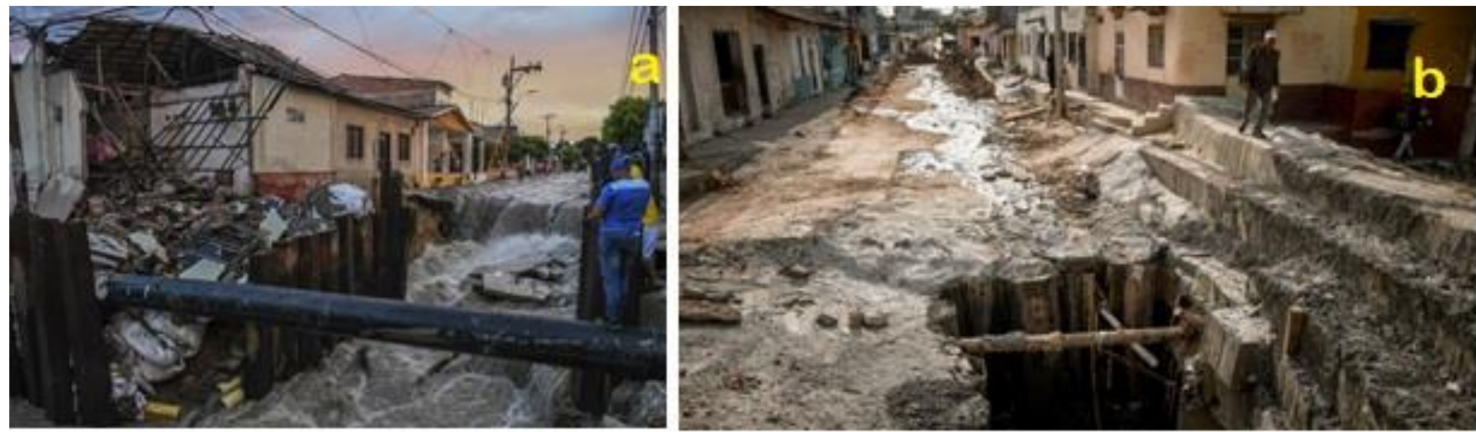

Figure 3. (a) Flooding and its impacts in the HOSPITAL stormwater runoff channel. (b) Canalization works for the HOSPITAL stormwater runoff channel, Street 79 (Source: Mayor's Office of Barranquilla).
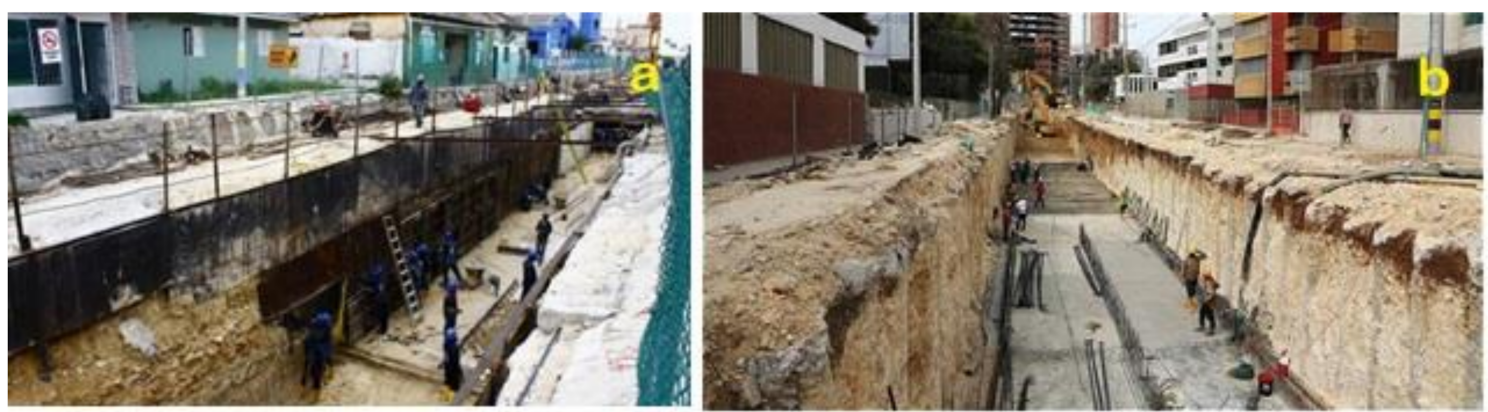

Figure 4. (a,b) Stormwater runoff channel works in the BMA (Source: Mayor's Office of Barranquilla).
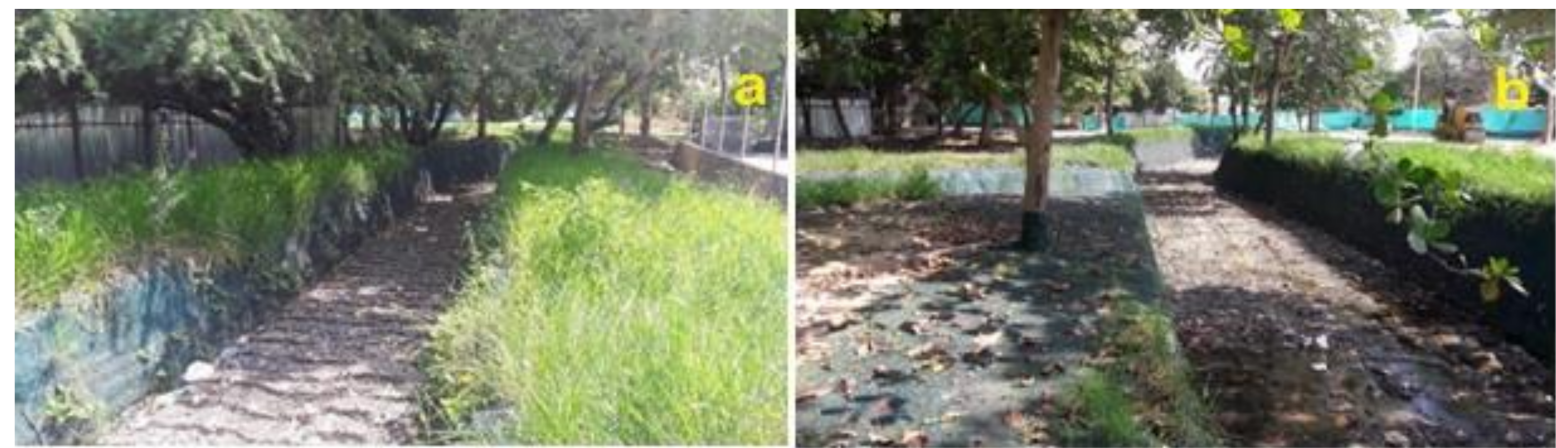

Figure 5. $(\mathbf{a}, \mathbf{b})$ Canalization of the Botanical Garden stormwater runoff channel with adaptation measures to the natural environment (Source: Mayor's Office of Barranquilla).

Regarding the perception of risk in the four studied communities of the BMA, the questionnaire conducted in 391 households addressed local people's knowledge of hazards and their response strategies. Only $11 \%$ of respondents were part of a social organization and $9 \%$ reported having been involved in risk prevention projects.

In terms of response capacity, we found that $50 \%$ had telephone contact with the police authority and $60 \%$ were aware of the emergency care lines. Concerning the knowledge as to what to do in an emergency, $55 \%$ of respondents said they did not know what to do. Seventy-one percent of the participants reported knowledge on the prevention of vector diseases.

One outstanding aspect relates to the respondents' exposure to hazards. Results suggest that the most hazardous aspects were perceived to be anthropogenic and related to citizen security, as opposed to natural and socio-natural events. This reflects a now well-known fact that poor population are more concerned with everyday risk than with events that occur sporadically, are temporally dispersed and are the subject of attention by local or national governments. Although respondents rated most 'environmental' hazards, 
such as fires, with low values, in the "Adelita de Char" and "La Cangrejera" neighborhoods, the highest rating was for stream flooding and landslides. This result relates to the high levels of exposure of the inhabitants to these hazards historically and corroborates findings of previous research that identified high levels of awareness about the risk of urban stream floods $[39,46,47,58]$ and landslides $[45,58]$.

The results highlight the fact that the BMA has high socio-cultural vulnerability derived from society's low organizational capacity, inequality in life conditions, and the general ignorance of the population in terms of hazards and risk management issues. Educational strategies are lacking, and there are no community systems of preventive alerts based on strategic communication. In the BMA, vulnerable communities are mostly composed of people living in extreme poverty or marginality due, amongst other things, to the inadequate provision of public services, such as those related to health. These disadvantaged areas lack opportunities for income generation, signifying constant social degradation and insecurity. A better understanding of which people and systems are vulnerable to specific hazards and perceptions about them are necessary to improve risk management governance. We suggest a deeper analysis of this aspect in future studies.

\subsubsection{Level of Effectiveness of Government Entities in Managing Multi-Hazard Scenarios}

This section presents the weaknesses and strengths detected in governance. The level of effectiveness of BMA government entities in the face of hazards was also analyzed. Results were derived from the opinions of surveyed epistemic experts and community members who participated in the four focus groups. The aspects analyzed had an institutional, territorial, and socioeconomic focus. These elements can be considered for improving public governance and for facing multi-hazard scenarios in the BMA (See Table 3).

Table 3. Weaknesses and strengths detected in public governance policy according to the capacity to respond to already identified hazards.

3. Poor identification of the hazard hierarchy in planning and risk management

plans for BMA.4. An increasing number of low-income households in BMA.

5 . Poor performance by public officials in charge of disaster risk management in BMA.

6. Increase in migrant settlements towards the western slopes in the capital of BMA due to deficient territorial and land use control.

7. Increase of the areas exposed to the risk of flooding, such as the land surrounding the Magdalena River wetlands.

8 . Little awareness and empowerment of citizens regarding biotic and abiotic resource management, (especially water).

9. Low level of government response to some hazards.

10. Little attention to families living in precarious conditions.

11. Increased land invasion in high-risk areas that are not "liberated" but

reoccupied by resettled migrants.

12. High densification in specific city sectors and restricted use of green areas, open spaces, and recreational areas.

13. BMA transformed by anthropic interventions.

14. Little implementation of corrective and preventive measures to relocate populations from high-risk areas, improving their livelihoods, employment rate, access to services.

15. Insufficient promotion of urban agriculture.

16. Weak government management to minimize mitigable environmental risks and hazards such as atmospheric pollution.

17. Proliferation of commercial activities in residential areas.

18. Unjustified delays in the relocation processes affecting populations due to hazards like landslides and granular flows.

19. Few urban planning initiatives to change the use of liberated territories and convert them into recreational or productive public space.

20. Occupation of fragile local ecosystems and vulnerable areas in the BMA.

22. Serious problems due to poor solid waste management inside the newly built rainwater runoff channels, caused by the lack of an environmental culture in the population living in BMA (See Figure 6a-d).

23. Corruption and centralization are considered as the most significant problems to overcome for facing hazards on the territory. Some measures require the authorization of the national government to obtain economic resources. 24. Limited infrastructure and personnel capacity to attend emergencies, especially in the health system.

25. Poor adoption of measures for adapting to climate change in planning and risk management plans.
}

1. Local governments have carried out different actions in the search to increase the knowledge of hazards among the inhabitants of the BMA.

2. Several local authorities and decision-makers have managed resources to promote investments to solve the impacts of hazards. Channeling of the streams in the capital of BMA is the most important action (See Figures 3-5). 3. BMA is increasingly attractive to investments.

4. Development of new studies to update the management of flooding hazard in BMA.

5. Design and implement structural measures developed to control impacts on hydrographic basins [42-44].

6. Government strategies include funds for the construction of artificial conduits retention or detention works, channelling and sediment control, as well as new collectors and water storage works, which improves the macro-drainage network of the streams (See Figure 4).

7. Government approval of investments to improve the micro-drainage network in the capital city of BMA, which guarantees efficient underground and surface drainage (See Figure 5).

8. Development of government measures for maintenance and cleaning of canals, as well as other prevention and management actions related to raising public awareness and control of impacts derived from final disposal of solid urban waste (See Figure 7)

9. High level of human capital formation.

10. Small territory that allows execution of integrated strategies.

11. Academic sector willing to contribute to solving problems.

12. Private sector ready to enter public-private alliances, as well as to address identified and characterized risk scenarios, especially technological risk. 


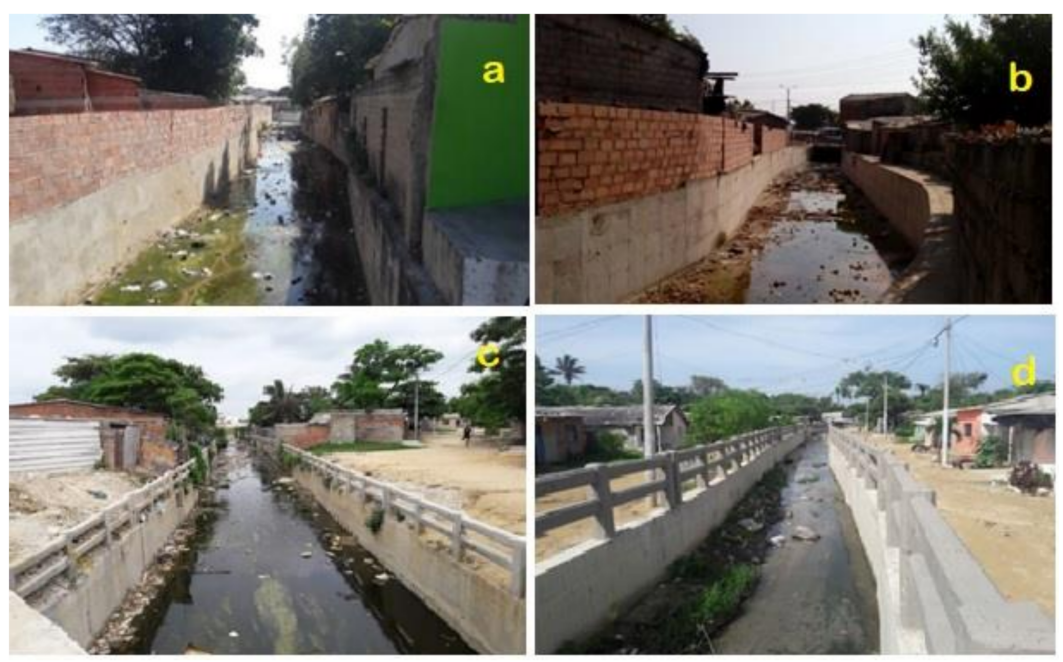

Figure 6. Presence of solid waste in different stormwater runoff channels in BMA. (a) Stormwater runoff channel "El Afan" (Neighborhood San Nicolas); (b) Stormwater runoff channel "Don Diego" (Neighborhood Simon); (c) La Paz Bicentennial stormwater runoff channel; (d) Stormwater runoff channel Village-Sourdis. (Source: Mayor of Barranquilla, 2020).
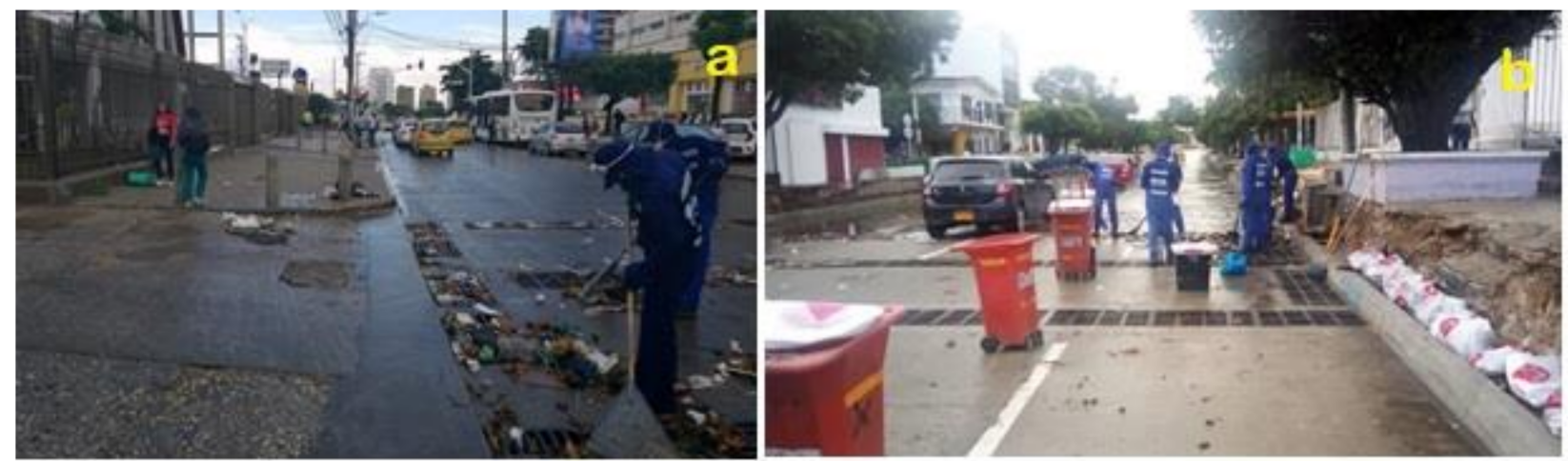

Figure 7. $(\mathbf{a}, \mathbf{b})$ Government actions to avoid obstruction of recently constructed stormwater runoff channel. (Source: Mayor of Barranquilla, 2020).

In this phase, research revealed 25 weaknesses and 12 strengths among the measures designed to face identified hazards. Epistemic experts in risk management concluded that although planning and risk management officers recognize hazards due to floods and landslides, there are still insufficient management options given the magnitude of the problem. Sixty three percent of experts stated that greater attention should be paid to the continuous migration to and settling of population on urban slopes as well as areas affected by floods, like the perimeter areas of the Magdalena River wetlands.

Forty-five percent of experts mentioned government strengths in reducing problems related to floods. However, other important hazards for the region are not addressed with the same hierarchy, such as landslides, granular flows, coastal erosion, and social hazards.

Although the impact of flooding originating in stormwater runoff channels has been reduced due to management actions by the government, some canalized stormwater runoff channels continue to be dangerous. This is due to inadequate waste management practices resulting in obstruction of channels (See Figures 6 and 7).

We undertook a detailed review of Law 1523, 2012, which created the so-called National System for Disaster Risk Management [59], in order to analyze and evaluate the level of effectiveness of government entities in the BMA in managing multi-hazard scenarios. The law designates the members of the Departmental Council for Risk Management (in Sp. 
CDGR), an organization that forms part of the Disaster Risk Management System at the departmental level.

Within the Institutional Platform on Risk Issues in the BMA, the Department of Atlántico issued Decree No. 0504 of 23 July 2012 [60]. This determined how both the CDGR of the Atlantic and Departmental Committees are to be organized. Departmental Committees are structured in three committees: (1) Departmental Committee for Risk Knowledge, (2) Departmental Committee for Risk Reduction, and (3) Departmental Committee for Disaster Management.

The Atlantic Departmental Council (Sp. CDGR) complies with operational-level instructions. The Governor or his delegate presides over it. The Secretary of Health, Secretary for Infrastructure, Deputy Secretary for Risk Management or the entity in charge of the Department's DRM, as well as Directors or Managers of public service entities or their delegates, the director of the Regional Autonomous Corporation of the Atlantic, a Delegate of the Regional Autonomous Corporation of Rio Grande de la Magdalena CORMAGDALENA, the Director of the Colombian Civil Defence of the Department, the Director of the Departmental Colombian Red Cross, the Departmental Delegate of Firefighters, Commander of Departmental Police or his delegate and Commander of Military Unit, also participate [39].

The roles of these institutions were analyzed by 75 performance' experts in the four focus groups, as well as 40 epistemic experts. Results obtained are recorded in Table 4.

Table 4. Results as to the effectiveness of government management of urban risk in the BMA. (Caption: Focal Group 1 to 4 (FG-1, FG-2, FG-3, FG-4).

\begin{tabular}{|c|c|c|c|c|c|}
\hline \multirow[b]{2}{*}{ Institutions } & \multicolumn{5}{|c|}{ Assessment Scale } \\
\hline & $\begin{array}{c}1 \\
(\text { Bad) }\end{array}$ & $\begin{array}{c}2 \\
\text { (Poor) }\end{array}$ & $\begin{array}{c}3 \\
\text { (Regular) }\end{array}$ & $\begin{array}{c}4 \\
\text { (Good) }\end{array}$ & $\begin{array}{c}5 \\
\text { (Very Good) }\end{array}$ \\
\hline Mayor's Office & & & 23 & 10 & 7 \\
\hline Barranquilla Verde & & 2 & 19 & 11 & 8 \\
\hline Government & & & 14 & 15 & 11 \\
\hline Departmental Health Secretariat & 1 & 1 & 18 & 15 & 5 \\
\hline District Health Secretary & & & 16 & 14 & 10 \\
\hline Departmental infrastructure secretary & & & 22 & 12 & 6 \\
\hline District infrastructure secretary & 2 & 3 & 25 & 7 & 3 \\
\hline Departmental Undersecretary for Disaster Risk Management & & & 17 & 14 & 9 \\
\hline District Risk Management Office & & & 9 & 15 & 16 \\
\hline Regional Autonomous Corporation of the Atlantic, (Sp. CRA) & & & 28 & 10 & 2 \\
\hline $\begin{array}{l}\text { Regional Autonomous Corporation of Rio Grande de la Magdalena } \\
\text { (Sp. CORMAGDALENA) }\end{array}$ & & 1 & 30 & 8 & 1 \\
\hline Colombian Civil Defense Department. & & & 36 & 4 & \\
\hline Colombian Red Cross of the Department. & & & 12 & 18 & 10 \\
\hline Atlantic Firefighters & & & 14 & 18 & 8 \\
\hline Commander of the Departmental Police or his delegate & 2 & 3 & 28 & 6 & 1 \\
\hline Military Unit & & & 32 & 5 & 3 \\
\hline Weighted total value of Institutions (I) & 0.3 & 0.6 & 21.4 & 11.4 & 6.3 \\
\hline FG-1 & & & 19 & & \\
\hline FG-2 & & & & 19 & \\
\hline FG-3 & & & 18 & & \\
\hline FG -4 & & & 19 & & \\
\hline Weighted total value (I+FG) & 0.3 & 0.6 & 77.4 & 30.4 & 6.3 \\
\hline
\end{tabular}

Table 4 shows the result of the assessment of the effectiveness of government management of urban risk in BMA. With $77.4 \%$ of the total weighted value, effectiveness was 
classified as regular. Most experts consulted consider that several institutions from CDGR in the Atlantic Department have not achieved an adequate level of hazard management.

\subsubsection{Model of Governance to Face Disaster Risk Management in the BMA}

This third and final section presents a governance model for managing multiple hazards and increasing urban resilience in the BMA. The proposal for this governance model is presented in Figure 8.

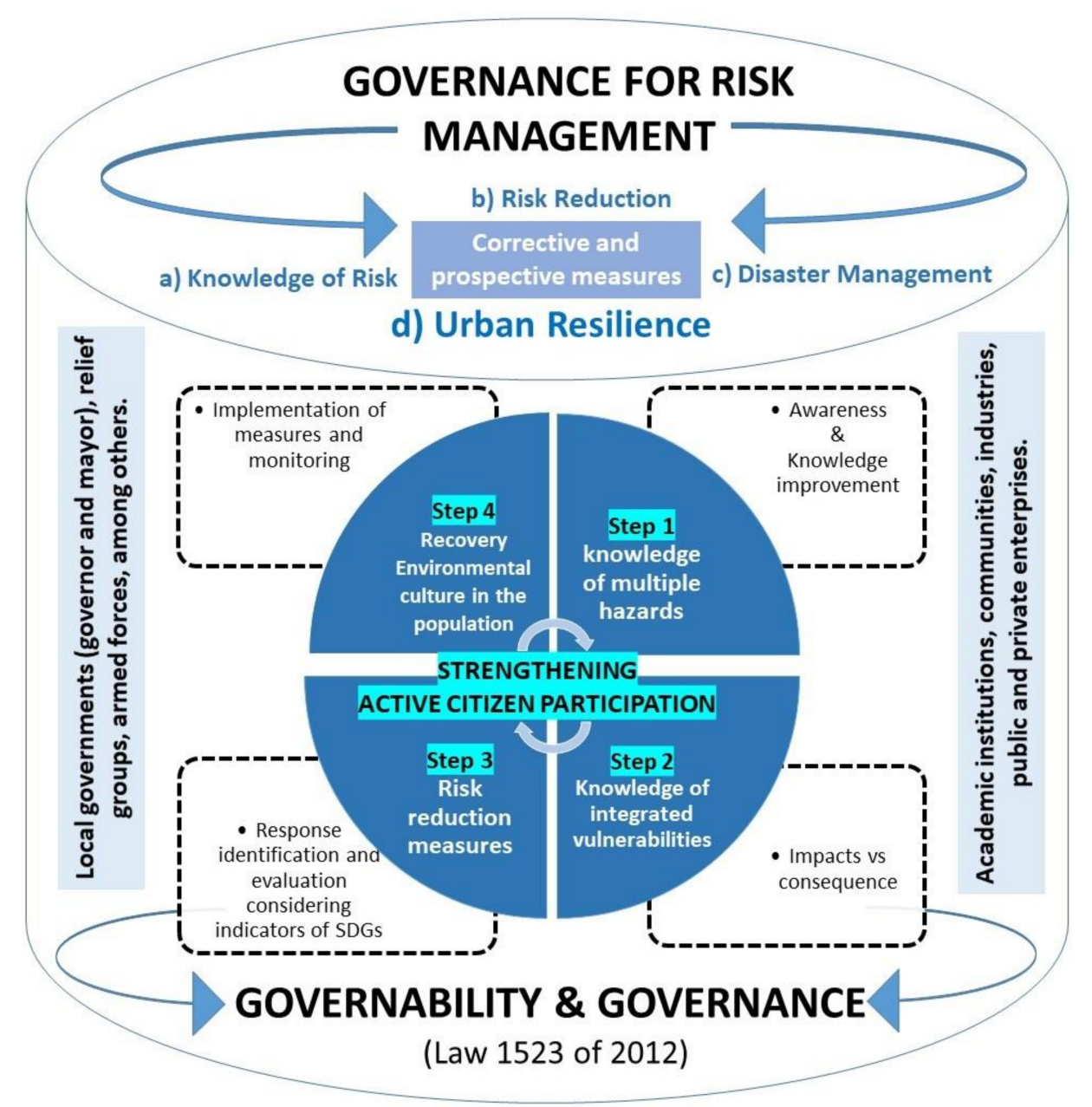

Figure 8. Governance model to improve urban resilience and risk management in the BMA.

The approach of local governments to risk management in the BMA has focused on floods and conservation of nature more than on adaptation measures to face multiple hazards [61]. Considering that disaster risk materializes when there is vulnerability to hazards of natural, socionatural, technologic, or anthropogenic origin, our proposed model aims to intervene in the causes that have perpetuated exposure to hazard in the territory and to the existence and growth of vulnerability.

The model is based on the integration of comprehensive government actions to guarantee efficient and timely attention when implementing corrective and prospective measures (Corrective refers to the reduction of existing risk factors. Propective refers to the anticipation of future risk avoiding the creation of new risk factors). Our proposal reinforces management actions favoring improvements in risk knowledge and understanding, which are still insufficiently dealt with in Colombia $[9,23,58,62]$. The proposal is also based on the legal framework for disaster risk management in Colombia [59]. In Article 2, on liability, the law promotes the exercise of Governance, granting responsibilities to public, private, 
and community entities for risk management within the framework of their competencies and as components of the National System of Disaster Risk Management.

For achieving proper risk management, the active participation of civil society $[58,63]$, as well as the training of expert technicians in the prevention and control of risks is crucial [64] (p. 1). Civil society must contribute to the design and implementation of public policies, improving their quality, guaranteeing their integrity and security according to principles of sustainable development $[65,66]$. Because of this responsibility, the Governance Model for Disaster Risk Management proposed in this research integrates procedures, protocols, and indicators described in Law 1523 [59] with actions that local government and civil society must undertake.

The model is based on four steps: (1) Strengthening knowledge and understanding of multi-hazard scenarios. Actions to raise the awareness and knowledge base of the communities and entities with responsibilities for the different hazards; (2) Strengthening knowledge on integrated vulnerabilities. This includes actions to identify impacts and consequences of hazards, as well as degrees of exposure and vulnerability of the territory, analyzed using a participatory approach; (3) Strengthening of risk reduction and control measures. This includes actions for identifying and evaluating possible responses to emergencies. The use of sustainable development indicators to minimize risks is a relevant contribution of the model at this stage; and (4) Recovery of an environmental culture in the population. Actions aimed to implement measures for continuous monitoring of hazards, vulnerabilities, and risks with a SDG approach are also incorporated.

The recommended minimum scale for information collection and analysis is 1: 2000 . A systematic inventory of data can be carried out in this model. The model allows for a consideration of indicators such as streams contaminated by waste, number of people lacking environmental culture, among others, all impeding the fulfillment of the 2030 Agenda. As many authors [67] suggest, when monitoring is developed in the short term (each year), it is possible to detect trends.

The four phases of this model are based on active citizen participation.

\section{Discussion}

4.1. Relevant Aspects Regarding the Identification of Hazards and Public Perception of Hazards and Risks by Communities in the BMA

In Table 1, it can be appreciated that hazards of anthropogenic origin, environmental degradation, and air pollution, were the most representative in the BMA. Pollution has intensified in recent years. Recent research shows that atmospheric pollutants have increased with impacts not only on the population but also on the historic built heritage of the study region [68,69].

Regarding stream flooding, the result obtained in the review of risk management instruments in the BMA coincided with the results of research undertaken by INVEMAR [61]. BMA and the Department of Atlántico are the territories in the Caribbean area where the highest numbers of natural and anthropogenic events occur. The main hazard is flooding by the Magdalena River and its feeder streams and swamps.

From the 2020 Atlantic Vision Agenda [48], the hazards considered to have the highest incidence on risk in the BMA are landslides, granular flows, erosion, flooding, forest fire, and environmental pollution. Nevertheless, POMCAS [42-44] indicates landslides, erosion, and floods as the main hazards. They are followed in importance by forest fires, extortion, contamination of water bodies, atmospheric pollution, and spills of flammable substances. The land use planning and risk management tools consulted are not homogeneous in terms of the hierarchy levels and priority given to hazards.

With regards to coastal erosion, Table 2 shows several differences as compared to the results of research published by INVEMAR in 2018 [61]. In their research publication, 55\% of the coast of the BMA was assigned a certain level of damage due to erosion, with high and moderate levels identified on low coastal lands such as beaches. Another scientific publication that asserts the importance of this hazard for the BMA was published by 
Rangel et al, in the same year [70]. The authors conclude that the coast of Barranquilla has presented high rates of coastal erosion in the last twenty years.

The presence of COVID-19 and the highest level of impact assigned to this for the BMA is understandable because, when applying the survey, the Atlantic department reported 491 cases of contagion with a sustained increase in new infections and deaths [71]. In fact, the cases continue increasing today [72].

Although electric storms were identified by some experts, and it is in fact an important natural hazard for Colombia [73], this event is not reported as being relevant in the risk management tools analyzed $[39,41]$.

In the BMA, landslides were not relevant for the experts consulted. This analysis may have an implicit individualistic cultural bias. The interviewees stated that they did not fear the occurrence of this hazard. Many experts and community members in fact have personal experience with this type of event but still do not consider it that important. The result corresponds with literature about perception of risks amongst western slopes inhabitants of Barranquilla when faced with landslides [45]. According to that research, it is, however, necessary to include the risk of landslides in management strategies.

The consulted experts also reported gales. This result corresponds with the information obtained in stage 1 , where seven risk management plans $[24,39-41,45,46]$ recognize this hazard in the study area.

The exploitation of hydrocarbons offshore was identified by experts but is not present in the risk management tools analyzed. This anthropogenic hazard begins to concern some researchers because it is a potential risk on the BMA coast [74,75].

According to the analysis regarding perception of risk of hazards by communities in the BMA, the research revealed the inhabitants' capacity to respond to multiple hazards and risks. Social perception governs how people understand their physical and social world $[10,34,76,77]$. Results published in $[44,45]$ indicate that perception of hazards is related to social conditioning factors and highlights the fact that people's perceptions of hazards are both socially constructed (i.e., contextual) and subjective [76,78]. Therefore, social perception with regard to multi-dimensional hazards in the local context is important and is highlighted in our research.

\subsection{Relevant Aspects Regarding the Model of Governance to Face Disaster Risk Management in the $B M A$}

In the proposed model, governance for risk management is the key. It incorporates an urban resilience perspective based on knowledge and reduction of risk through disaster risk management and addresses the local context.

Our proposal differs from the methodology for assessing hazard, vulnerability, and disaster risk, including climate risk and cost-benefit assessment, for projects in pre-feasibility (phase II) and feasibility (phase III) phases [79] as carried out by the Colombian ministries of economy, finance, planning, and environment. One of the differences in our proposal is based on the scale. The aforementioned method uses 1:25,000 scales, while our proposal promotes hazards and risk assessments at a larger scale of 1:2000.

The model takes up on the weaknesses identified by the experts and converts them into opportunities for the generation of comprehensive policies, in which risk management is an instrument of planning, land use, and development. This also differs from the methodology designed to perform ecological risk assessments in coastal areas and focused on the ecosystem's health, prioritizing ecosystems' risks based on only four natural hazards [80].

The proposal considers the concept of "governance" because it is more encompassing than governability [81]. Environmental governance is in many ways like the concept of sustainable development because it provides a degree of cross-cutting integration of various interests, perspectives, and approaches, that may mean different things to different people [82,83].

Considering that governance refers to the capacity for implementing and enforcing decisions made by government authorities and stakeholders, governance is an exercise of power in a broader sense. It implies certain modalities of allocating resources, con- 
trol, and coordination, where government actors are not necessarily the most relevant participants $[84,85]$. For this reason, the model promotes these processes, linked to public participation.

Many weaknesses identified in the methodologies and manuals analyzed indicate the need to reduce inequalities [86,87]. It is important to create conditions for the population to gain access to participation, as well as education that allows greater control regarding their environment, the hazards in their territory, and mechanisms for participation in the construction of local development. In the proposed model, knowledge of risk must be understood from an appropriation of territory perspective and not only through knowledge of hazards.

Another relevant aspect of this model is the relationship with the stakeholders. Local governments, relief groups, and the armed forces play a relevant role in the implementation of measures, as well as in the monitoring of hazards, response, identification, and evaluation of risks. Therefore, the model articulates the role of local governments (governor and mayor), with relief groups, armed forces, among others, and with academic institutions, communities, industry, and public and private companies.

Finally, this model responds to the UN's SDGs and fulfillment of the 2030 Agenda. The model contributes to the SDG 11 entitled "Sustainable cities and communities" [88]. Specifically, to target 11.B based on Implementing Policies for Inclusion, Resource Efficiency, and Disaster Risk Reduction.

\section{Conclusions}

The BMA suffers from natural and anthropogenic hazards that are not sufficiently recognized by government entities with jurisdiction in the territory. Electrical storms and offshore hydrocarbon exploitation are amongst these. Atmospheric pollution and the COVID19 pandemic were identified as the most important hazards of anthropogenic origin. Experts agree that the hazard with the greatest recurrence in the BMA is flooding. This coincides with the most relevant hazards identified in all risk management plans consulted.

Channeling of the streams in the BMA has been implemented satisfactorily. However, poor urban discipline among the population and the lack of a civic culture to handle solid waste jeopardize these efforts. Several streams have been clogged due to an excess of solid waste. Therefore, the risk continues to increase.

The government's management of hazards in the BMA is classified as regular. The importance of monitoring multi-hazards and vulnerabilities following a holistic approach is highlighted, as well as the particpatory analysis of risks. A valid governance model has been designed not only for the BMA but also for other Colombian districts. The model incorporates the governance process as a key for increasing urban resilience and decision making. The model will be tested in the BMA by local institutions.

Author Contributions: Conceptualization, C.B.M.; methodology, C.B.M. validation, C.B.M., A.S.; A.S.J., M.B.M.-G., J.M.-G., S.E.P.-L.: investigation, C.B.M., A.S., M.B.M.-G., A.S.J., A.V.: resources, J.M.G., A.S.J., A.L.; writing—original draft preparation, C.B.M., A.S.J., M.B.M.-G., A.S., writing—review and editing, C.B.M., A.S., M.B.M.-G., A.L., S.Z.; supervision, C.B.M.; project administration, J.M.G., A.L.; funding acquisition, A.L., J.M.-G., A.S.J. All authors have read and agreed to the published version of the manuscript.

Funding: This research was funded by Project "Knowledge in Action for Urban Equality-KNOW" Coordinated by the Development Planning Unit of University College London and by the UK Economic and Social Research Council (ESCR) under the Global Challenges Research Fund (GCRF).

Institutional Review Board Statement: The study did not involve humans or animals.

Informed Consent Statement: The study did not involve humans or animals.

Data Availability Statement: Data supporting reported results can be found asking directly of the first author. 
Acknowledgments: The research leading to the present article was undertaken in the frame of Work Package 2 on resilience, poverty, and prosperity of the project "Knowledge in Action for Urban Equality-KNOW" globally coordinated by the Development Planning Unit of University College London, funded by the UK Economic and Social Research Council (ESCR) under the Global Challenges Research Fund (GCRF), and undertaken by research teams in Colombia, Costa Rica and Peru under the coordination of Allan Lavell at the Latin American Social Science Faculty in Costa Rica. Our sincere thanks to all the coordinators, funders, and researchers involved in the KNOW project as well as to all key informants and participants in the co-production research process.

Conflicts of Interest: The authors declare no conflict of interest.

\section{Appendix A. List of Job' Experts Participants in the Focus Groups}

Focal Group 1

\begin{tabular}{cc}
\hline Institutions & Number of Experts \\
\hline Carnival S.A. & 1 \\
\hline University del Norte & 1 \\
\hline Public Works & 2 \\
\hline District Secretary of Education & 1 \\
\hline Coast Guard & 1 \\
\hline UPTC & 1 \\
\hline Cormagdalena & 1 \\
\hline Army & 2 \\
\hline Medical mission & 2 \\
\hline Mayor's Office & 3 \\
\hline University of the Coast & 2 \\
\hline CUL University & 1 \\
\hline Risk Management Mayor's Office & 2 \\
\hline Total & $\mathbf{2 0}$ \\
\hline
\end{tabular}

Focal Group 2

\begin{tabular}{ccc}
\hline Institutions & Number of Experts \\
\hline Harbor Master & 3 \\
\hline University del Norte & 2 \\
\hline Army & 3 \\
\hline Mayor's Office & 2 \\
\hline APELL & 2 \\
\hline University of the Coast & 1 \\
\hline Autonomous University of the Caribbean & 2 \\
\hline Consultant & 2 \\
\hline National Navy of Colombia & 1 \\
\hline Tepartmental Undersecretary for Disaster Risk Management & 2 \\
\hline Total & 20 \\
\hline
\end{tabular}

Focal Group 3

\begin{tabular}{cc}
\hline Institutions & Number of Experts \\
\hline Oceanographic and Hydrographic Research Center & 1 \\
\hline Red Cross & 2 \\
\hline Mayor's Office & 1 \\
\hline Government & 1 \\
\hline Departmental Health Secretariat & 3 \\
\hline
\end{tabular}




\begin{tabular}{cl}
\hline District Health Secretary & 2 \\
\hline District infrastructure secretary & 1 \\
\hline Departmental Undersecretary for Disaster Risk Management & 2 \\
\hline District Risk Management Office & 2 \\
\hline Regional Autonomous Corporation of the Atlantic, (Sp. CRA) & 3 \\
\hline Military unit & 2 \\
\hline Total & $\mathbf{2 0}$ \\
\hline
\end{tabular}

\section{Focal Group 4}

\begin{tabular}{cc}
\hline Institutions & Number of Experts \\
\hline Regional Autonomous Corporation of the Atlantic, (Sp. CRA) & 3 \\
\hline APELL & 2 \\
\hline Secretary of culture & 2 \\
\hline Simon Bolivar University & 2 \\
\hline Naval School of Barranquilla & 2 \\
\hline District Secretary of Education & 1 \\
\hline District Secretary of Culture & 1 \\
\hline Local government & 1 \\
\hline District Health Secretary & 1 \\
\hline Total & $\mathbf{1 5}$ \\
\hline
\end{tabular}

\section{Appendix B. List of Epistemic Experts Participates in the Questionnaire} Institutions

1. Mayor's Office

4

2. Barranquilla Verde

2

3. Government

3

4. Departmental Health Secretariat

2

5. District Health Secretary

6. Departmental infrastructure secretary

2

7. District infrastructure secretary 3

8. Departmental Undersecretary for Disaster Risk Management 4

9. District Risk Management Office 4

10. Regional Autonomous Corporation of the Atlantic, (Sp. CRA) 2

11. Regional Autonomous Corporation of Rio Grande de la Magdalena (Sp. CORMAGDALENA) 2

12. Colombian Civil Defense Department

13. Colombian Red Cross of the Department. 


\section{References}

1. Bathrellos, G.D.; Karymbalis, E.; Skilodimou, H.D.; Gaki-Papanastassiou, K.; Baltas, E.A. Urban flood hazard assessment in the basin of Athens Metropolitan city, Greece. Environ. Earth Sci. 2016, 75, 319. [CrossRef]

2. Cutter Susan, L. Compound, Cascading, or Complex Disasters: What's in a Name? Environment 2018, 60, 16-25. [CrossRef]

3. Daniel, G.-S.; Adolfo, Q.-R.; José Juan, Z.-O. Geomorphological hazards susceptibility in high-density urban areas: A case study of Mexico City. J. S. Am. Earth Sci. 2020, 102, 102667.

4. Quesada-Román, A.; Fallas-López, B.; Hernández-Espinoza, K.; Stoffel, M.; Ballesteros-Cánovas, J.A. Relationships between earthquakes, hurricanes, and landslides in Costa Rica. Landslides 2019, 16, 1539-1550. [CrossRef]

5. Quesada-Román, A.; Villalobos-Portilla, E.; Campos-Durán, D. Hydrometeorological disasters in urban areas of Costa Rica, Central America. Environ. Hazards 2020, 1-15. [CrossRef]

6. Adolfo, Q.R.; Andy, V.C. Flash flood impacts of Hurricane Otto and hydrometeorological risk mapping in Costa Rica, Geografisk Tidsskrift-Danish. J. Geogr. 2020, 120, 142-155. [CrossRef]

7. Batista, M.C. Coastal risk. In Encyclopedia of Coastal Science, 2nd ed.; Finkl, C.W., Makowski, C., Eds.; Springer Nature: Cham, Switzerland, 2018; Volume 1, pp. 524-534.

8. Milanés, B.C.; Suarez, A.; Botero, C.M. Novel method to delimitate and demarcate coastal zone boundaries. Ocean Coast. Manag. 2017, 144, 105-119. [CrossRef]

9. Botero, C.M.; Arrizabalaga, M.; Milanés, C.; Vivas, O. Indicadores de gobernabilidad para la gestión del riesgo costero en Colombia. Revista Luna Azul. 2017, 45, 227-251. [CrossRef]

10. Batista, M.C. Coastal flood hazard mapping. In Encyclopedia of Coastal Science, 2nd ed.; Finkl, C.W., Makowski, C., Eds.; Springer Nature: Cham, Switzerland, 2018; Volume 1, pp. 471-479. [CrossRef]

11. Milanés, C.B.; Montero, O.P.; Szlafsztein, C.F.; Márcia Aparecida da Silva, P. Climate change and spatial justice in coastal planning in Cuba and Brazil. Ambiente Soc. 2020, 23, e01841. [CrossRef]

12. Milanés, B.C.; Hidalgo Zambrano, R.V. Ciudades Bajo Riesgo Costero: Los Casos de Santiago de Cuba y Portoviejo. Arquit. Y Urban. 2018. Available online: rau.cujae.edu.cu/Índex.php/revistaau/article/view/501/473 (accessed on 18 April 2020).

13. Milanés, B.C.; Cochero Cermeño, R.; Meza Estrada, C.E. Riesgos en Ciudades Costeras de Colombia: Los Casos de Barranquilla y Cartagena de Indias. In Experiencias Metodológicas Para la Gestión del Riesgo. Libro de Investigación; Milanés, B.C., Szlafsztein, C.F., Eds.; Editorial Universitaria de la Costa, EDUCOSTA S.A.S.: Barranquilla, Colombia, 2018; pp. 193-208. Available online: http:/ / repositorio.cuc.edu.co/xmlui/handle/11323/1686 (accessed on 15 January 2020).

14. Marco, J.B.; Cayuela, A. Urban flooding: The flood-planned city concept. In Coping with Floods; Rossi, G., Harmancioğlu, N., Yevjevich, V., Eds.; NATO ASI Series (Series E: Applied Sciences); Springer: Dordrecht, The Netherlands, 1994 ; Volume 257.

15. Arellana, J.; Fuentes, L.; Cantillo, J.; Alvarez, V. Multivariate analysis of user perceptions about the serviceability of urban roads: Case of Barranquilla, International. J. Pavement Eng. 2021, 22, 54-63. [CrossRef]

16. Avila, H.; Avila, L.; Sisa, A. Dispersed Storage as Stormwater Runoff Control in Consolidated Urban Watersheds with Flash Flood Risk. J. Water Resour. Plan. Manag. 2016, 142, 12. [CrossRef]

17. Milanés, B.C.; Hidalgo Zambrano, R.V. Diagnóstico y Prospectiva para la Gestión del Riego de Desastres en un Cantón Vulnerable: Portoviejo. In Experiencias Metodológicas Para la Gestión del Riesgo. Libro de Investigación; Milanés, B.C., Szlafsztein, C.F., Eds.; Editorial Universitaria de la Costa, EDUCOSTA S.A.S.: Barranquilla, Colombia, 2018; pp. 141-161. Available online: http: / / repositorio.cuc.edu.co/xmlui/handle/11323/1686 (accessed on 19 February 2020).

18. Avila, H. Perspectiva del manejo del drenaje pluvial frente al cambio climático. Caso de estudio: Ciudad de Barrnaquilla, Colombia. In Revista de Ingeniería Universidad de los Andes; Universidad de los Andes: Bogotá, Colombia, 2016; Volume 36, pp. 54-59.

19. Berrocal, Ó. Muere Mujer que Fue Arrastrada por Temible Arroyo en Barranquillla. 2019. Available online: https://www. eltiempo.com/colombia/barranquilla/muertes-por-arroyos-en-barranquilla-366420 (accessed on 14 April 2020).

20. Botero, C.M.; Pereira, C.I.; Milanes, C.B.; Pranzinid, E. Dataset of human interventions as anthropogenic perturbations on the Caribbean coast of Colombia. Data Brief. 2020, 31, 105847. [CrossRef] [PubMed]

21. Migración. Ingreso y Permanencia de Venezolanos en Colombia. Subdirección de Control Migratorio. 24 May 2020. Available online: https://www.migracioncolombia.gov.co/venezuela (accessed on 15 February 2021).

22. Santana, P.M.; Cochran, A.; Bell, C.; Hernández Jiménez, U.; Leshner, E.; Trejo Morales, F.; Chatman, D.G. Bus rapid transit arrives in Barranquilla, Colombia: Understanding a changing landscape through residents' travel experiences. Travel Behav. Soc. 2020, 21, 31-139.

23. Botero, C.; Milanés, C. Aportes para la Gobernanza Marino-Costera. Gestión del Riesgo, Gobernabilidad y Distritos Costeros. In Libro de Investigación; Fondo de Publicaciones de la Universidad Sergio Arboleda: Bogotá, Colombia, 2015 ; p. 554.

24. Plan de Ordenamiento Territorial. Alcaldía de Barranquilla. 2014. Available online: https://www.barranquilla.gov.co/ transparencia/planeacion/politicas-lineamientos-y-manuales/planes-estrategicos/plan-de-ordenamiento-territorial (accessed on 10 April 2020).

25. Milanés, B.C. Método Integrado para Demarcar y Delimitar las Zonas Costeras (DOMIZC): Estudio del Caso de Santiago de Cuba. Ph.D. Thesis, Universidad de Oriente, Santiago de Cuba, Cuba, 2014. Available online: https://www.researchgate.net/ profile/Celene_Milanes_Batista3 (accessed on 28 January 2020). 
26. Rumson, A.G.; Payo, G.A.; Hallett Stephen, H. The role of data within coastal resilience assessments: An East Anglia, UK, case study. Ocean Coast. Manag. 2020, 185, 105004. [CrossRef]

27. Holling, C.S. Resilience and stability. Annu. Rev. Ecol. Syst. 1973, 4, 1-23. [CrossRef]

28. Holling, C. Engineering resilience versus ecological resilience. In Engineering within Ecological Constraints; Schulze, P., Ed.; The National Academies Press: Washington, DC, USA, 1996.

29. de Dios Uriarte Arciniega, J. La Perspectiva Comunitaria de la resiliencia. Psicol. Política 2013, 47, 7-18. Available online: https:/ / www.uv.es/garzon/psicologia\%20politica/N47-1.pdf (accessed on 6 May 2020).

30. Kolb, C.L. Resiliencia. Psiquiatría Clínica Moderna. Prensa Médica Mex. 1983, 725, 103.

31. Twigg, J. Características de una Comunidad Resiliente ante los Desastres. Available online: http://www.benfieldhrc.org/ disaster_studies/projects/communitydrrindicators/comunity_drr_indicators_index.htm2017 (accessed on 14 November 2019).

32. ONU-Habitat. Ciudades Resilientes. Available online: https:// onuhabitat.org.mx/index.php/ciudades-resilientes (accessed on 11 April 2020).

33. UNISDR - The United Nations Office for Disaster Risk Reduction. Cómo Desarrollar Ciudades más Resilientes. Un Manual para Líderes de los Gobiernos Locales. 2012. Available online: www.unisdr.org/campaign (accessed on 16 April 2020).

34. Batista, C.M.; Tamayo, H.A.; Alvarez, J.R.N. Application of Business Intelligence in studies management of Hazard, Vulnerability and Risk in Cuba. Iop Conf. Ser. Mater. Sci. Eng. 2020, 844, 012033. [CrossRef]

35. Milanés, B.C.; Szlafsztein, C.F. Experiencias Metodológicas Para la gestión del Riesgo; Editorial Universitaria de la Costa, EDUCOSTA S.A.S.: Barranquilla, Colombia, 2018; p. 208. Available online: http://repositorio.cuc.edu.co/handle/11323/1076 (accessed on 6 June 2020).

36. Urban Resilience Hub by ONU-Habitat. Available online: https:/ / urbanresiliencehub.org/ (accessed on 11 April 2020).

37. Padilla-Llano, S. Producción de espacio público [X] Participación ciudadana. El proyecto de espacio público resultado de procesos de participación ciudadana. Tesis para optar al grado de Doctor en Espacio Público y Regeneración Urbana. Arte, Teoría y Conservación del Patrimonio. Ph.D. Thesis, Universitat de Barcelona, Barcelona, Spain, 2015. Available online: http:/ / diposit.ub.edu/dspace/handle/2445/66978 (accessed on 20 April 2020).

38. Weinstein, B.D. What is an expert? Theor. Med. 1993, 14, 57-73. [CrossRef]

39. PDGRA (Plan Departamental de Gestión del riesgo Atlántico). Gobernación del Departamento del Atlántico; PNUD-UNGRD, National Unit for Disaster Risk Management: Bogotá, Colombia, 2012; 133p. Available online: https:/ / repositorio.gestiondelriesgo. gov.co/handle/20.500.11762/392 (accessed on 22 January 2020).

40. Alcaldía de Barranquilla. POT (Plan de ordenamiento territorial 2012-2032) Documento Técnico de Soporte-Libro I: Componente General Secretaria de Planeación. 2012. Available online: https:/ / www.uninorte.edu.co/documents/73923/1041591/DTS_POT_ 2012_gral.pdf/9b0ea384-bb12-429c-a215-a43f7aafb339?version=1.0 (accessed on 13 April 2020).

41. PGRDDEIPB. Plan de Gestión del Riesgo de Desastres del Distrito Especial, Industrial y Portuario de Barranquilla, DEIP 2017-2032; District Risk Management Council: Barranquilla, Colombia, 2012; 212p. Available online: https://es.scribd.com/document/4741 18860/PLAN-DISTRITAL-GESTION-RIESGO-OCT-5-2018-1-pdf (accessed on 22 January 2020).

42. Planes de Ordenamiento y Manejo de Cuencas POMCAS del departamento del Atlántico Rio Magdalena. 2007. Available online: https: / es.slideshare.net/mileidy227 / plan-de-ordenamiento-y-manejo-de-la-cuenca-hidrica-del-rio-magdalena-enel-departamento-del-atlantico (accessed on 6 September 2020).

43. Planes de Ordenamiento y Manejo de Cuencas POMCAS del Departamento del Atlántico Ciénaga de Mayorquín. 2010. Available online: http:/ / www.crautonoma.gov.co/atencion-al-publico/transparencia-y-acceso-a-informacion-publica/planeacion/plande-ordenamiento-y-manejo-de-las-cuencas-hidrograficas (accessed on 16 April 2020).

44. Planes de Ordenamiento y Manejo de Cuencas POMCAS del Departamento del Atlántico Canal de Dique. 2016. Available online: http:/ / www.crautonoma.gov.co/atencion-al-publico/transparencia-y-acceso-a-informacion-publica/planeacion/plande-ordenamiento-y-manejo-de-las-cuencas-hidrograficas (accessed on 6 December 2020).

45. PMILO. Plan de Manejo Integral Ladearas Occidentales de Barranquilla. Alcaldía de Barranquilla. 2015. Available online: http:/ / web2018.barranquilla.gov.co/normatividad/leyes-y-acuerdos/cat_view/374-opaed/376-plan-laderas-2015 (accessed on 6 August 2020).

46. Plan de Desarrollo 2016-2019. Alcaldía de Barranquilla, Colombia. 2016. Available online: https://www.barranquilla.gov.co/ transparencia/planeacion/politicas-lineamientos-y-manuales/planes-estrategicos/plan-de-desarrollo (accessed on 18 April 2020).

47. Alcaldía de Barranquilla. Plan Maestro de Arroyos. 2014. Available online: https://studylib.es/doc/5732028/plan-maestro-dearroyos---alcald\%C3\%ADa-de-barranquilla (accessed on 6 October 2020).

48. Visión Atlántico 2020: La Ruta para el Desarrollo. DNP (Departamento Nacional de Planeación). 2011. Available online: https:/ / colaboracion.dnp.gov.co/CDT/Prensa/Publicaciones/7-VISION\%20ATLANTICO.pdf (accessed on 16 September 2020).

49. Decree No. 0212 de 2014 por el cual se Adopta el Plan de Ordenamiento Territorial del Distrito Especial, Industrial y Portuario de Barranquilla 2012-2032. Gaceta Distrital. Available online: https://barranquilla.eregulations.org/media/Decreto\%200212\%2 0de\%202014\%20adopta\%20POT.pdf (accessed on 9 April 2020).

50. Lavell, A.; Brenes, A. Segregación Socioespacial, Riesgo de Desastre y su Gestión: Un Resumen y Recomendaciones; Informe de la Alcaldía de Barranquilla: Mayoralty of Barranquilla, Colombia, 2018; 19p. 
51. Espinoza, G.L.M. La Construcción Social del Riesgo, una Perspectiva para la Gestión del Riesgo en Barranquilla. Trabajo de grado Como Requisito para Optar por el Título de Magíster en Desarrollo Sustentable y Gestión Ambiental; Universidad Distrital Francisco José de Caldas: Bogotá, Colombia, 2016; Available online: http:/ / repository.udistrital.edu.co/bitstream/11349/5065/1 /EspinosaGarciaLuzMarina2016.pdf (accessed on 23 August 2020).

52. El Plan de Desarrollo de Barranquilla Recibió las Propuestas de Expertos en Gestión de Riesgo. Available online: https:/ /www lametronoticias.com/el-plan-de-desarrollo-de-barranquilla-recibio-las-propuestas-de-expertos-en-gestion-de-riesgo/ (accessed on 6 March 2020).

53. Plan de Desarrollo de Barranquilla Recibió las Propuestas de Expertos en Gestión de Riesgo. Available online: https: / / diariolalibertad.com/sitio/2020/03/06/plan-de-desarrollo-de-barranquilla-recibio-las-propuestas-de-expertos-en-gestionde-riesgo/ (accessed on 18 April 2020).

54. Alcaldía de Barranquilla. Plan de Desarrollo. Soy Barranquilla 2020-2023. NIT 890.102.018-1. Available online: https://www. barranquilla.gov.co/transparencia/planeacion/politicas-lineamientos-y-manuales/planes-estrategicos/plan-de-desarrollo (accessed on 22 September 2020).

55. De Barrera, J.H. Metodologia de la Investigacion Guia de la Comprensiónholística de la Ciencia; Quirón Ediciones: Valladolid, Spain, 2010; 1309p, Available online: https://books.google.com.co/books/about/Metodolog\%C3\%ADa_de_la_Investigaci\%C3\%B3n. html?id=P-EatAEACAAJ\&redir_esc=y (accessed on 28 April 2019).

56. De Gutiérrez, L.R. De la Regeneración Urbana a la Gentrificación. Caso Estudio en Barranquilla, Colombia. Ph.D. Thesis, Universidad de Granada, Granada, Spain, 2018. Available online: http:/ / digibug.ugr.es/handle/10481/50914 (accessed on 18 July 2020).

57. Henríquez, E.L. Reflexiones Acerca del Papel de las Élites locales en la Estructuración del Espacio Metropolitano de Barranquilla y Cartagena; Polifonía Caribe: Barranquilla, Colombia, 2017; 147p, Available online: https:/ /bit.ly /2PBJE3f (accessed on 20 May 2020).

58. Milanés, B.C.; Galbán, R.L.; Olaya, C.N.J. Amenazas, Riesgos y Desastres: Visión Teórico-Metodológico y Experiencias Reales; Libro de investigación: Barranquilla, Colombia, 2017; 306p, Available online: https://repositorio.cuc.edu.co/handle/11323/1156 (accessed on 22 April 2020).

59. Ley 1523 de 2012 por la cual se Crea el Sistema Nacional para la Gestión del Riesgo de Desastres. Gobierno de Colombia, Administrative Department of Public Function Mayor's Office of Bogota, Official Gazette: Bogota, Colombia, 2012; 22p. Available online: https:/ / www.alcaldiabogota.gov.co/sisjur/normas/Norma1.jsp?i=47141 (accessed on 22 April 2020).

60. Decree No. 0504. 23 July 2012; National Unit for Disaster Risk Management: Bogota, Colombia. Available online: http:/ /www. gestiondelriesgopasto.gov.co/new /index.php/recomendaciones/incendios-estructurales2/20-home/61-estructura-cmgrd\# :text=DECRETO \%20No.,0504\&text=0963\%20del\%2027\%20de\%20diciembre,y\%20se\%20dictan\%20otras\%20disposiciones (accessed on 22 January 2020).

61. Ricaurte-Villota, C.; Coca-Domínguez, O.; González, M.E.; Bejarano-Espinosa, M.; Morales, D.F.; Correa-Rojas, C.; BriceñoZuluaga, F.; Legarda, G.A.; Arteaga, M.E. Amenaza y Vulnerabilidad por Erosión Costera en Colombia: Enfoque Regional para la Gestión del Riesgo; "José Benito Vives De Andréis"; INVEMAR: Marta, Colombia, 2018; 268p.

62. Milanés, C.; Lastra, R.; y Sierra-Correa, P. Estudios de Caso sobre Manejo Integrado de Zonas Costeras en Iberoamérica: Gestión, Riesgo y Buenas Prácticas, 1st ed.; Corporación Universidad de la Costa: Barranquilla, Colombia, 2019; 465p, Available online: https:/ / repositorio.cuc.edu.co/handle/11323/5502 (accessed on 6 June 2020).

63. Batista, M.C. Coastal Boundaries. In Encyclopedia of Coastal Science, 2nd ed.; Finkl, C.W., Makowski, C., Eds.; Springer Nature: Cham, Switzerland, 2018; Volume 1, pp. 414-426.

64. Fernández, P.; Ceacero-Moreno, M. Urban Sustainability and Natural Hazards Management; Designs Using Simulations. Sustainability 2021, 13, 649. [CrossRef]

65. PNUD Sustainable Development Goals. Available online: https://www.undp.org/content/undp/es/home/sustainabledevelopment-goals.html (accessed on 15 June 2020).

66. Sachs, J.D. From Millennium Development Goals to Sustainable Development Goals. Lancet 2012, 379, 2206-2211. [CrossRef]

67. Pierre, F.; Gardic, G.T.; Benjamin, D.; Oumar, S.; Marie-Suzanne, T. Perception of threats and related management measures: The case of marine protected areas in West Africa. Marine Policy. 2020, 117, 103936.

68. Gallego-Cartagena, E.; Héctor, M.; Maguregui, M.; Patiño-Camelo, K.; Iker, M.; Wendy Morgado, G.; Luis, F.O.S.; Madariaga, J.M. A comprehensive study of bioflms growing on the built heritage of a Caribbean industrial city in correlation with construction materials. Int. Biodeterior. Biodegrad. 2020, 147, 104874. [CrossRef]

69. Silva, F.O.L.; Milanes, C.; Pinto, D.; Ramirez, O.; Lima, B.D. Multiple hazardous elements in nanoparticulate matter from a Caribbean industrialized atmosphere. Chemosphere 2020, 239, 124776. [CrossRef] [PubMed]

70. Rangel-Buitrago, N.; Williams, A.T.; Anfuso, G. Hard protection structures as a principal coastal erosion management strategy along the Caribbean coast of Colombia. A chronicle of pitfalls. Ocean Coast Manag. 2018, 156, 58-75. [CrossRef]

71. Tikitakas. Mapa de Casos y Muertes por Coronavirus por Departamentos en Colombia. Available online: https://colombia.as. com/colombia/2020/05/03/tikitakas/1588504168_561963.html (accessed on 28 April 2020).

72. Alcaldía Distrital de Barranquilla. COVID-19 Cifras Oficiales. Available online: https://experience.arcgis.com/experience/e3af9 acb3ed44fbfb850ec4f3f161ece (accessed on 17 January 2021). 
73. Cruz, M.C.A. Evaluación del Riesgo por Rayos Incluyendo un Sistema de Alarma de Tormentas (SAT) en Colombia. Programa de Adquisición y Análisis de Señales PAAS. Ph.D. Thesis, Universidad Nacional de Colombia, Facultad de Ingeniería, Departamento de Ingeniería Eléctrica y Electrónica, Bogotá, Colombia, 2015. Available online: http://bdigital.unal.edu.co/52646/1/ carlosalbertocruzmosquera.2015.pdf (accessed on 3 April 2020).

74. Rueda, B.J.G.; Guzman, A.; Cabello, E.J.J.; Silva-Casarín, R.; Bastidas-Arteaga, E.; Horrillo-Caraballo, J. Renewables energies in Colombia and the opportunity for the offshore wind technology. J. Clean. Prod. 2019, 220, 529-543. [CrossRef]

75. Pereira, C.I.; Carvajal, A.F.; Milanés, B.C.; Botero, C.M. Regulating human interventions in Colombian coastal areas: Implications for the environmental licensing procedure in middle-income countries. Environ. Impact Assess. Rev. 2019, 79, 106284. [CrossRef]

76. Perez, M.O.; Milanes, B.C. Social perception of coastal risk in the face of hurricanes in the southeastern region of Cuba. Ocean Coast. Manag. 2020, 184, 105010.

77. Batista, C.M.; Planas, J.A.; Pelot, R.; Núñez, J.R. A New Methodology Incorporating Public Participation Within Cuba's ICZM Program. Ocean Coast. Manag. 2020, 186. p. 105101. [CrossRef]

78. Cui, K.; Ziqiang, H. Association between disaster experience and quality of life: The mediating role of disaster perception of risk. Qual. Life Res. 2018, 28, 509-513. [CrossRef] [PubMed]

79. Miniambiente. Metodología Para Evaluar los Riesgos. Available online: https://www.dnp.gov.co/programas/ambiente/gestiondel-riesgo/Documents /2.\%20Metodolog\%C3\%ADa\%20para\%20evaluar\%20los\%20riesgos.pdf (accessed on 15 August 2020).

80. Andrea, Y.; Botero Camilo, M.; Miriam, A.; Jairo, G.V. Methodological proposal for ecological risk assessment of the coastal zone of Antioquia, Colombia. Ecol. Eng. 2019, 130, 242-251.

81. Valdes, U.F. Gobernanza e instituciones: Propuestas para una agenda de investigación. Perf. Lat. 2008, 16, 95-119.

82. Paavola, J. Institutions and environmental governance: A reconceptualization. Ecol. Econ. 2007, 63, 93-103. [CrossRef]

83. Molina, D. Gobernanza ambiental en Colombia: La acción estatal y de los movimientos sociales. Ambiente Desarro. 2017, 18, 27-42. [CrossRef]

84. Brenner, L.; Vargas Del Rio, D. Gobernabilidad y gobernanza ambiental en México: La experiencia de la Reserva de la Biosfera Sian Ka'an. Polis 2010, 6, 115-154.

85. Bulkeley, H. Reconfiguring environmental governance: Towards a politics of scale and networks. Political Geogr. 2005, 24, 875-902. [CrossRef]

86. Manual de Gestión Inclusiva de Emergencias: Derechos Humanos de las Personas con Discapacidad Durante Emergencias; Kaiser, C.; Vásquez, A.; Vásquez, D. (Eds.) Ediciones Universidad Tecnológica Metropolitana: Peñaflor, Chile, 2013; 96p, Available online: https:/ / reliefweb.int/sites/reliefweb.int/files/resources/Manual_de_ddhh_personas_con_discapacidad_en_emergencias. pdf (accessed on 28 November 2020).

87. ONG Inclusive. Propuesta de Plan Nacional de Acción Inclusivo en Discapacidad Frente a COVID-19. Available online: https://onginclusiva.org/wp-content/uploads/2020/12/Propuesta-plan-nacional-de-accion-inclusiva-en-discapacidadfrente-a-covid.pdf (accessed on 15 July 2020).

88. ODS. Available online: http://los17ods.org/los-17-objetivos-para-2030/ciudades/ (accessed on 10 December 2020). 